\title{
Sadagura, a special smokeless tobacco preparation with or without areca nut induced genotoxicity, sperm abnormality as well as oxidative stress in vivo in Swiss albino mice
}

\author{
Dr. Salam Himika Devi
}

Guest Faculty Genetics and Genotoxicology Branch, Department of Zoology (Life Sciences), Manipur University, Type III Quarter new block near community hall, 1st floor, Western side, Room no. 32, Indo-Myanmar Road, Canchipur-795003, Imphal-West, Manipur, India

DOI: 10.29322/IJSRP.11.11.2021.p11962

http://dx.doi.org/10.29322/IJSRP.11.11.2021.p11962

\begin{abstract}
Sadagura a special smokeless tobacco preparation is being very popular in southern part of Assam, North -East India. The study is the first report on the genotoxic effect associated with the sadagura (SG) with or without areca nut (AN) extract in vivo in albino mice. Analysis of chromosome aberration (CA), micronucleus (MN) were performed in the bone marrow cells and sperm head abnormality (SHA) assay, total sperm count (TSC) were done in germ cells compared with control. A significant increased in the frequency of CA was found in AN+SG extract treated group (24.33\%, P<0.001), MN (4.59\% PCEs, P<0.01) respectively, SHA (13.46\%, $\mathrm{P}<0.001)$ and TSC $(17.98, \mathrm{P}<0.001)$. The genotoxic effects brought about by the extracts were dose dependent. However, most highest rise in the frequency of CA was observed at the combine AN+SG treated group at $24 \mathrm{~h}$ exposure, which was highly significant at $(\mathrm{P}<0.001)$ compare with AN and SG alone treated groups and negative control. There was a time dependent decreased in the frequency of CAs. AN with or without SG showed statistically significant impairment of SHA and reduce TSC suggesting the role of test extracts in male germ cell toxicity. Result of lipid peroxidation indicates that exposure of SG and AN extracts leads to a significant induction of cytogenetic damage in bone marrow cells, male germ cell toxicity as well as substantial increase in oxidative stress in liver of mice. These results could provide valuable information about the cause of oral precancerous and malignant transformation in betel quid chewers.
\end{abstract}

\section{INTRODUCTION}

$\mathrm{L}$ ifestyle factors account for about $80 \%$ of human neoplasia cases [1]. Smokeless tobacco (ST) is the cheapest, easily available and most commonly used tobacco products in India. Sadagura is very popular special smokeless tobacco preparation used by the local population of the southern part of Assam, India. It mainly contains tobacco whose main alkaloid is nicotine. The strong flavor and stimulating effect associated with sadagura consumption ultimately results into addiction among users. It is chewed and swallowed mostly with betel quid containing areca nut (main alkaloid arecoline). The highest incidence of oral cancer in India is reported in Assam in the North-East region, where it is the second leading cancer among men and third among women [2]. Therefore, it becomes important to assess the genotoxicity of new tobacco preparations like sadagura alone or in combination with areca nut consumption. Betel quid alone or in combination with smokeless tobacco and/or smoking has been considered as major risk factors for oral cancer and precancerous lesions in habituates [3]. Consumption of sadagura with or without areca nut often leads to increased incidence of micronucleus and other nuclear abnormalities in the buccal epithelial cells of human population study [4].

The local population consumes sadagura along with betel quid containing areca nut on large scale without knowing its harmful effects. They usually expose the buccal epithelial cells directly to the test substances for longer time period from morning till night by consuming one quid after another. It is also important to note that the site within the oral cavity, where carcinoma usually develops, is the place where quid is placed for prolonged period [5]. There is reported cases of betel quid chewing stimulates mitosis during wound healing and exposes germinal basal cells to genotoxins and infection by HVP [6]. Epidemiological studies have documented that the habit of chewing betel quid is major risk factor in the causation of oral cancers. Tobacco and areca nut are the main suspected sources of carcinogens and/or their precursors in betel quid. Tobacco has shown a close correlation between the manner of its consumption and the development of site specific cancers. There is a high probability that compounds that exhibit genotoxic activity will also exhibit carcinogenic activity. In vitro genotoxic effects of areca nut extract and arecoline was shown by using Chinese Hamster ovary cells [7]. By considering the above facts we are trying to give an insight into the genotoxicity induced by sadagura (SG) extract alone or in combination with the areca nut (AN) extract in vivo in albino mice. There is already published paper regarding genotoxicity of arsenic exposure and SG by bone marrow micronucleus assay, sperm head abnormality (SHA) assay as well as lipid peroxidation assay [8]. However, there is no available data of genotoxicity study of SG and/or areca nut extract in mice. This study is the first report of genotoxicity induced by SG extract in vivo in juvenile mice. Genotoxicity was tested by using cytogenetic endpoints like bone marrow 
Chromosomal aberration (CA) and Micronucleus (MN) assays. Germ cell toxicity by Sperm head abnormality (SHA) assay and Total sperm count (TSC) per epididymis using Haemocytometer. CA assay constitutes a set of efficient, reliable and fundamental assay for evaluating the in vivo genotoxicity in mice. Hence, CA assay was developed to study such structural and numerical abnormalities and this technique provides reliable and sensitive information regarding genetical alterations induced by various chemicals and mutagens [9]. Micronucleus (MN) assay of bone marrow cells is one of the fundamental assays by which the genotoxicity of a test substance can be determined [10]. We also try to see the effect on germ cells by studying SHA which is a reliable and widely used technique to determine toxicity potential of test substances and is often used for mutagenicity and toxicological studies in mice [11-14]. Oxidative stress evaluation was also carried out in liver tissues because of their essential role in metabolizing various toxic compounds in the body. Lipid peroxidation assay relies on the measurement of level of malonaldehyde (MDA) in the tissue which in turn is useful in estimating the extent of oxidative damage caused to the lipid integrity [15]. Therefore, this study is focusing on mechanism of induction of carcinogenesis by considering both genotoxicity and oxidative stress by releasing ROS by considering SG alone or in combination with AN in treated mouse.

\section{MATERIALS AND METHODS}

\subsection{Reagents}

Glacial acetic acid, Methanol, Sodium chloride $(\mathrm{NaCl})$, Potassium chloride $(\mathrm{KCl})$ was purchased from Qualigens. Colchicine was purchased from Sigma chemicals Co. (St Louis, MO). Giemsa's stain, Eosin Y stain, Tricarboxylic acid (TCA), Thiobarbituric acid (TBA) were procured from Himedia Laboratories Pvt. Ltd., Mumbai, India. Mitomycin C (MMC) was obtained from Cadila Pharmaceuticals, India. Dimethyl sulphoxide (DMSO) was purchased from S.D. Fine-chem. Limited, Mumbai, India.

All other chemicals were purchased from Himedia and Qualigens. All the reagents used for treatment, buffer were freshly prepared in distilled water before administration into the test system and prior to experimentation respectively.

2.2 Animals

Male Swiss albino mice (Mus musculus) 10-12 weeks old and weighing between 22-28 g purchased from the Pasteur Institute, Shillong (Meghalaya, India) were used in this study. The present investigation was conducted with due permission and proper guidelines from the Animal Ethics Committee Assam University, Silchar.

The advantage of using mouse as a model is that it posses proliferating cells both in somatic (bone marrow) and germinal (testes) tissues, which makes the genotoxicity studies more convenient. Animals were caged in solid-walled plastic cages with stainless steel mesh lids. They were housed in a group of two/three in small cages and four-six in large cages. Animals were maintained under conventional laboratory conditions at room temperature $26.0 \pm 5.0^{\circ} \mathrm{C}$ and in $12-\mathrm{h}$ light/dark cycle. Mice were provided with standard food pallet and water ad libitum. Cages were cleaned twice weekly. The experiments were conducted as per Assam University Institutional Animal Ethical Committee guidelines.

Three animals were selected for every experiment of genotoxicity studies since mice were selected from closely inbred colony there would be less probability of genetic divergence among the animals. Hence, a very small size of animals (3) animals for genotoxic experiments would suffice the purpose as genetical response of the animals towards the chemical would not vary much from each other.

\subsection{Treatment schedules and dose levels}

The treatment schedules of the bone marrow CA, MN tests as well as lipid peroxidation assay are illustrated in Table 1. For SHA assay animals were treated with AN, SG and AN+SG extracts for 14 consecutive days and scoring was done after 35 days from the first treatment day.

\subsection{Plant materials and extraction procedures}

\section{Areca nut extract}

For the preparation of AN extract, ripe, dry areca nuts were obtained from the local market of Irongmara, Silchar, India. After removal of the fibrous coats, the nuts were cut into thin slices, oven dried and powdered by using mixer-grinder. Preparation of extracts was following the protocol of [16] with minor modifications. Briefly, powdered AN was mixed with dichloromethane in (1:10 ratio) and kept in shaker at room temperature for $72 \mathrm{~h}$. The mixture were then filtered and dried. The residue was dissolved in DMSO at a concentration of $60 \mathrm{mg} / \mathrm{ml}$ and stored at $-20^{\circ} \mathrm{C}$ for further use.

Three acute doses 20,50 and $80 \mathrm{mg} / \mathrm{kg}$ body weight of AN was given orally by gavages (p.o) to Swiss albino mice for five consecutive days and scoring was done after 24 and $48 \mathrm{~h}$ of last treatment day, for genotoxicity and lipid peroxidation studies.

DMSO was used as a solvent and the extract solution was freshly prepared prior to the administration to the animals. The control animals received an equal volume of DMSO given orally. The animals tolerated the dose of extract without any sign of toxicity. The extract dose, their dilution and mode of administration was selected and based on literature survey and toxicity studies.

\section{Sadagura extract}

SG was prepared following local formulation with dried tobacco leaves, fenugreek seed and aniseed mixed in 2:4:1 ratio and all the ingredients were purchased from local market of Irongmara, Silchar, India. Then, the mixture was powdered. Now, the powdered mixture is locally called Sadagura (Figure 1). Preparation of extracts was following the protocol of [16] with minor modifications. 


\section{Areca nut with sadagura extract}

Areca nut with sadagura $(\mathrm{AN}+\mathrm{SG})$ extract was prepared in 1:1 ratio of AN powdered and SG. The powdered AN and SG were mixed with dichloromethane in (1:10 ratio) and kept in shaker at room temperature for 72 hour. Preparation of extracts was same as SG.

\subsection{Experimental protocols}

\section{Chromosome aberration assay}

CA assay was conducted following the protocols given by Preston et al., 1987 [17] and Krishna and Hayashi, 2000 [9] with minor modifications. Mice were injected i.p. with Colchicine ( $2 \mathrm{mg} / \mathrm{kg}$ body weight) $1 \mathrm{~h} 30 \mathrm{mins}$ prior to sacrifice and 24 and $48 \mathrm{~h}$ of the last treatment. Animals were killed by cervical dislocation and bone marrow cells were collected from both the femora by flushing in $\mathrm{KCl}\left(0.56 \%\right.$ pre warmed at $\left.37^{\circ} \mathrm{C}\right)$ and cells were incubated for $18-20$ mins at $37^{\circ} \mathrm{C}$ and fixed in $1: 3$ aceto-methanol for minimum 30 mins in cold (refrigerator). Centrifugation for 5 mins was repeated twice with fresh aceto-methanol. The material, resuspended in a small volume of the fixative, the slides were prepared by dropping the sample on to the chilled slides from a height of 2 feet and run over the frame, flame-dried. The prepared slides were stained the following day in 5\% Giemsa stain.

By this technique 100 well spread metaphase chromosome plates are observed under microscope and structural changes in chromosome like breaks, gaps, exchanges, Robertsonian translocation, sister chromatid union could be detected (Figure 2) and scored as indicated in Table 2 and 3.

\section{Mitotic Index}

Mitotic index is the percent ratio of number of dividing cells to the total number of cells observed.

$$
\text { Dividing Cells }
$$

Mitotic index $(\mathrm{MI})=\quad \frac{\mathrm{X} 100}{\mathrm{~T}}$

Total number of cells studied

\section{Micronucleus (MN) assay}

Preparation of bone marrow smears and staining was done following the method of Schmid W. 1975 [18]. The bone marrow cells were flushed out and collected in $0.9 \% \mathrm{NaCl}$ pre-warmed at $37^{\circ} \mathrm{C}$. Smear was prepared, air-dried and fixed in methanol for 10 mins. Staining was done in 5\% Giemsa stain following day. The slides were mounted with cover slip using DPX for microscopic study.

The polychromatic erythrocytes (PCEs) are the early maturing stage of RBC taking light blue stain due to the presence of residual nucleic acids whereas normochromatic erythrocytes (NCEs) are the older maturing stage of RBC and stain light reddish to transparent (Figure 3) due to the absence of nucleic acids in it. Total 2000 PCEs and its corresponding number of NCEs were analyzed separately per mice for the presence of $\mathrm{MN}$.

The ratio of PCE/NCE was scored to evaluate the cytotoxic effect of the chemicals tested. A PCE/NCE ratio was significantly lower than that from the solvent control indicating a decrease in the number or rate of erythrocytes maturation, revealing cytotoxicity.

\section{Sperm head abnormality (SHA) assay:}

The animals were sacrificed by cervical dislocation after 35 days of exposure. Both the cauda epididymis were dissected out and placed in $1 \mathrm{ml}$ of $0.9 \%$ normal saline $(\mathrm{NaCl})$. The sperms were released by mechanical disruption and washing of the epididymis following [19]. The suspension was sieved through two layers of muslin cloth to remove the tissue debris. A drop of the suspension was taken on a clean glass slide and a smear was made, air dried, and fixed in absolute methanol for 10 mins. The slides were stained in the following day in $0.1 \%$ eosin $\mathrm{Y}$ for 10 mins.

Total 1000 sperms per animal were analyzed and scored different types of abnormalities such as normal sperm, amorphous, beaked, hooked, hookless, altered head, triangular, banana, pin-headed, giant, dwarf, double-headed, and some new, additional types such as mushroom, pea-nut, bent at cephalocaudal junction, bent at projecting filament (Figure 4).

\section{Total sperm count:}

Testes were dissected out and epididymis was carefully separated and minced in $1 \mathrm{ml}$ of $\mathrm{NaCl}(0.9 \%)$ to obtain a suspension [20]. The suspension was filtered through a nylon mesh. The total sperm count was performed in the filtrate as per the standard method in Neubauer's chamber [20,21]. An aliquot from the suspension (up to 0.5) was taken in leukocyte Haemocytometer and diluted with $\mathrm{NaCl}$ up to mark 11. The suspension was well mixed and 1 or 2 drops was putted into the Neubauer's counting chamber. The total sperm count in 8 squares (except the central erythrocyte area) of $1 \mathrm{~mm}^{2}$ each was determined and multiplied by $5 \times 10^{4}$ to express the number of spermatozoa/epididymis following Narayana et al., 2005 [22].

Total sperm count analysis was also an important parameter indicating the toxic effects of test substances/ chemicals on the spermatogenesis. This assay is used as a short-term bioassay to investigate the mutagenic or cytotoxic effects of agents responsible for significant human exposure. In addition, epidemiological evidences indicate that semen quantity in humans has declined progressively over the past 50 years with a general increase in the incidence of male reproductive pathogenesis including testicular cancer [23].

Lipid peroxidation ( $L P O)$ assay:

After sacrifice of mice, liver was removed, cleaned and weight in digital balance. Liver tissue was crush by using Pestle and Mortar, which was kept in a plastic container containing ice - cubes. Tissue homogenate was prepared in ice-cold normal saline and 
centrifuged for $10 \mathrm{mins}$ at $3000 \mathrm{rpm}$. The supernatant was used for estimation of the biochemical attribute i.e., lipid peroxidation for assessment of induction of oxidative stress in liver was done by the method of [15] and expressed as nmol malonaldehyde/g wet tissue. The step by step procedure is given as follows:

1. $1 \mathrm{ml}$ of sample (homogenate containing $0.8-0.9 \mathrm{mg}$ of protein) was incubated at $37 \pm 0.5^{\circ} \mathrm{C}$ for $2 \mathrm{~h}$.

2. To each sample, $1 \mathrm{ml}$ of $10 \% \mathrm{w} / \mathrm{v}$ TCA was added.

3. After through mixing, the mixture was centrifuged at $2000 \mathrm{rpm}$ for $10 \mathrm{mins}$.

4. To $1 \mathrm{ml}$ of supernatant, an equal volume of $0.67 \%$ TBA was added, kept in boiling water bath for 10 mins.

5. After cooling, it was diluted with $1 \mathrm{ml}$ of distilled water.

6. The absorbance was read at $535 \mathrm{~nm}$.

\section{Calculations:}

The malonaldehyde concentration (MDA) of the sample was calculated by using extinction coefficient of $1.56 \times 10^{5} \mathrm{M}^{-1} \mathrm{~cm}^{-1}$. The concentration of MDA expressed in $\mu \mathrm{molL}^{-1}$ was calculated by using Beer-Lambert law,

$$
\mathbf{A}=\mathbf{\epsilon} \mathbf{c} \mathbf{l}
$$

where, $\mathrm{A}=$ Absorbance;

$$
\begin{aligned}
& \epsilon=\text { Extinction coefficient; } \\
& \mathrm{c}=\text { concentration of MDA; } \\
& 1=\text { path-length }(1 \mathrm{~cm} \text { standard Curvette }) .
\end{aligned}
$$

Since the conversion of $\mu \mathrm{molL}^{-1}$ to $\mathrm{n} \mathrm{mol} / \mathrm{g}$ involves dividing and multiplying by 1000 , these steps essentially cancel out, so that $\mu$ molL ${ }^{1}=\mathrm{nmolml}^{-1}$. Therefore, the original MDA concentration in $\mu \mathrm{molL}^{-1}$ can be simply converted to the final concentration of $\mathrm{n}$ mol/g wet weight by the following calculation:

$\left(\mathrm{MDA} \mu \mathrm{molL}^{-1} \mathrm{x}\right.$ volume normal saline $\left.\mathrm{ml}\right) / \mathrm{g}$ wet weight $=\mathrm{MDA} \mathrm{n} \mathrm{mol} / \mathrm{g}$ wet weight

\section{Determination of malonaldehyde:}

TBA test is probably the single most widely used single assay for the measurement of lipid peroxidation. The sample under test is treated with TBA at low $\mathrm{pH}$, and a pink chromogen is measured. In the TBA reaction, one molecule of MDA reacts with two molecules of TBA with the production of a pink pigment with an absorption maximum at $535 \mathrm{~nm}$ (Figure 5).

\subsection{Statistical Analysis}

One-way analysis of variance (ANOVA) was used to determine the significance of the parameters using GraphPad Prism software. Pair wise comparison between the study groups was determined by using Tukey's multiple comparison tests. p-value of <0.05 was considered to be significant.

\section{RESULT}

\section{Chromosome aberration assay:}

The animals tolerated the doses without any visible sign of toxicity. All the treated animals were then sacrificed and the effects of the AN with or without SG extract in three different doses were tested by using bone marrow CA assay. In our study, MMC administered intraperitoneally (i.p) at the dose of $2 \mathrm{mg} / \mathrm{kg}$ BW was used as a positive control.

A linear increased in the frequency of CAs with increasing acute dose was observed in all the dose of AN, SG and AN+SG extract used after $24 \mathrm{~h}$ exposure time (Table 2). It was observed that there was a statistically significant increase in CAs in all the treated groups as compared to the control group. There was a dose dependent increase in percentage of CA in all the treated groups and groups receiving both $\mathrm{AN}$ and SG extract. In addition, a synergistic effect of $\mathrm{AN}+\mathrm{SG}$ extract as compared to only AN or only SG was observed in the tested dose range (Figure 6). However, there was time dependent decrease in the frequency of CAs with the increase in exposure time when comparison was done for 24 and $48 \mathrm{~h}$ exposure data. The percentage of MI remains almost similar in both 24 and $48 \mathrm{~h}$ exposed groups within the tested dose of AN (Table 3).

\section{Micronucleus assay:}

All the doses of AN, SG and AN+SG extract induced MN formation in the PCEs. When compared to the control group the lowest and middle dose show increased percentage of MN-PCE but not statistically significant. However, the highest dose of AN extract induced MN-PCE at $\mathrm{P}<0.01$ level when compare to the control group (Figure 7). This result is at per our result with $\mathrm{CA}$ study. A dose dependent decreased in PCE/NCE ratio was observed with increase in extract dose used (Table 4). A similar trend was observed after $48 \mathrm{~h}$ exposure time.

A comparative profile of $\mathrm{MN}$ for both 24 and $48 \mathrm{~h}$ studies of $\mathrm{AN}$ and $\mathrm{SG}$ extracts alone or in combination treatment is represented in Figure 7. The result indicates that AN+SG extract exhibited increase in the frequency of MN-PCE as compared to AN extract and SG extract treated alone which was as per CA assay. Among the three extracts tested, AN+SG extract showed highest degree of genotoxicity. There was an increased in MN-PCE with increasing dose of tested compounds which are statistically significant as compare to the control. A declining trend was observed in all the cases after $48 \mathrm{~h}$. 


\section{Sperm head abnormality assay and total sperm count:}

The results indicate that highest dose of AN+SG3 $(80 \mathrm{mg} / \mathrm{kg} / \mathrm{BW})$ generated maximum frequency of abnormal sperms $(13.46$ \pm 1.10 ) when compared to AN extract and SG extract (Table 5). All the extracts induced dose dependent increase in SHA. Interestingly AN and SG alone and in combined showed statistically significant impairment of SHA $(p<0.001)$ when compared to the control, suggesting the role of test substances in male germ cell toxicity. It is also observed that AN extract strongly induced SHA but to a lesser extent then SG extract (Figure 8). AN extract was showing the minimum level of toxicity as far as SHA is concerned.

\section{Total sperm count}

A dose dependent decrease in the total sperm count was observed in case of all the extracts and tested dose range as compare to the control group (Table 5, Figure 9). However, there was no significant difference in the sperm count among the treatment groups themselves. The reduction in sperm count induced by highest dose of AN+SG3 $(80 \mathrm{mg} / \mathrm{kg} / \mathrm{BW})$, AN3 and SG3 were $\left(17.98 \times 10^{6} \pm\right.$ $0.76),\left(19.50 \times 10^{6} \pm 0.82\right)\left(20.00 \times 10^{6} \pm 0.89\right)$ respectively, indicating no much variation.

\section{Oxidative Stress Measured as Lipid Peroxidation:}

There was a gradual increase in the hepatic MDA concentration from control group to the highest combined treated group. Highest dose of SG alone and AN + SG combined showed increased MDA levels which were $11.94 \pm 0.22$ and $11.57 \pm 0.30 \mathrm{nmol} \mathrm{MDA} / \mathrm{g}$ wet tissue respectively as compared to control value of $2.86 \pm 0.35 \mathrm{nmol} \mathrm{MDA} / \mathrm{g}$ wet tissue $(p<0.001)$ (Table 6$)$. It can be noted that SG and $\mathrm{AN}+\mathrm{SG}$ can cause lipid peroxidation as high as that cause by positive control Mitomycin $\mathrm{C}$.

\section{DISCUSSION}

The significant increase in the frequency of CA, MN and SHA as well as decrease in TSC in the AN alone or in combination with SG extract treated groups, indicates the genotoxic potential of sadagura. The test extracts also have genotoxic effects on germ cells of mice as well as have potential to cause oxidative stress as indicated by SHA assay and lipid peroxidation assay respectively. However, there is no previous report on AN extract and SG extract, smokeless tobacco preparation combined genotoxicity studies in mice test system. SG with AN extract combine is showing more genotoxicity may be because of synergistic effect of nicotine and arecoline. Previous report also said SG has the potential to cause genotoxicity in mouse bone marrow cells. SG can individually induce MN and SHA and lower sperm count, consumption of SG should be avoided at all cost [8].

Others forms of smokeless tobacco have been reported to induce genotoxicity [4]. Previous reports support our findings. SG is one of the most prevalent smokeless tobacco preparations in Southern Assam and is often chewed with betel quid or areca nut. There is limited literature available on SG and its association with the DNA damage. There are many types of the tobacco-areca nut specific nitrosamines that have been detected in the saliva of chewers [24]. Nicotine, which is a major alkaloid present in the tobacco leaves, is a weak clastogen [25]. Combustion of flavoring agents used in SG at the time of roasting may also produce hazardous pyrolysis products [4]. Some chemical spices, which are proved to be not mutagenic by Ames assay become mutagenic when treated with nitrite which is abundant in tobacco [26]. Therefore, the nitrite present in SG may react with otherwise non mutagenic dietary components and convert them into mutagenic species [3].

Tobacco (both smoke and smokeless forms) and betel quid use are the main risk factors for the development of head and neck squamous cell carcinoma (HNSCC) at concentrations $(0.0110 \mathrm{mM})$ relevant to tobacco chewers, nicotine major alkaloid [27]. Nicotine can directly activate the oncogene FOXM1 and the combined action of FOXM1 upregulation. Overexpression of forkhead box protein FOXM1 precedes HNSCC malignancy and also correlated with its progression [28]. Surprisingly, in human oral keratinocytes showed that nicotine, directly induced FOXM1 mRNA, protein stabilization and transcriptional activity at concentrations relevant to tobacco chewers. The novel targets of FOXM1are a centrosomal protein CE55 and a DNA helicase/putative stem cell markers HELLS, both located within a consensus loci (10q23) [28]. The co-carcinogenic effect of nicotine supports the finding that the risk of developing HNSCC is increased to 15 times higher in patients chewing betel quid with tobacco compared to chewing betel quid (areca nut) alone [29]. Previous reports also showed that arecoline major alkaloid of areca nut exerted a partial agonist activity with $\alpha 7-\mathrm{nAChR}$ in a dosedependent manner or with habitual use [30,31]. Areca nut extract is clearly both cytotoxic and genotoxic.

Our study shows induced the generation of reactive oxygen species by SG and AN extracts exposure in mice. Similar results are also found when arecoline induced the generation of reactive oxygen species and cell cycle arrest at the G1/G0 phase in human keratinocyte cells of $\mathrm{HaCaT}$ cell lines without affecting the exression of p21 [32]. Sublethal concentrations of arecoline upregulated the expression of the following stress responsive genes: heme oxygenase 1, ferritin light chain, glucose 6 phosphate dehydrogenase, glutamate cysteine ligase catalytic subunit and glutathione reductase. Arecoline also induced dose dependent induction of IL-1 $\alpha \mathrm{mRNA}$ via oxidative stress and p38 Mitogen activated protein kinase activation [32]. When the alkaloids are compared on a weight basis to the extract, no single agent has detectable effects on the cells at concentrations of the extract that causes decreased colony survival and DNA single strand breaks. Therefore, additive or synergistic effects could be considered among the various alkaloids. This findings support our findings as we have seen increased frequency of chromosome aberration, MN and SHAs when AN and SG extracts are given together. Areca nut contains various alkaloids mainly arecoline, arecaidine, guvacoline, guvacine among others. Arecoline the major alkaloid of areca nut produces 11 metabolites in mouse during the process of metabolism [33]. Further, the major composition of SG is tobacco. Tobacco contains major alkaloid nicotine. Tobacco specific alkaloids along with areca nut alkaloids may further potentiate the genotoxic and cytotoxic effects. Cytotoxicity may be caused by deregulation of cell cycle control, GSH homeostasis, mitochondrial 
dysfunction or reactive oxygen species production [34]. Tobacco specific alkaloids in combination with areca nut alkaloids may further enhance the cytotoxic effects. The induction of CA, MN in the bone marrow cells and impairment of the sperm head morphology in $\mathrm{AN}+\mathrm{SG}$ treated group could possibly indicate its additive effect which may involve a common mechanism in the form of causing more oxidative stress condition. Our results can extrapolate in explaining the mechanism of areca nut and tobacco induced carcinogenesis in human oral or mouth cancer. Thus, betel nut and tobacco chewers constitute high risk group for development of oral malignancies.

Long term exposure of test extracts show a significant increase in SHA and reduction in epididymal sperm count as compare with control group. AN and SG extracts have the potential to cross the testis-blood barrier and cause male germ cell toxicity by affecting normal morphology as well as reduced sperm count. SHA variation from the normal morphology may be due to mechanisms like alteration in testicular DNA or due to incidence of point mutation in testicular DNA, chromosomal aberrations which may occur during the packaging of genetic material in the sperm head [35, 36]. Exposure of chemicals could produce hormonal changes causing disturbances in normal spermatogenesis or could cause abnormalities in the seminal fluid leading to structural or functional impairment of the sperms [37]. The association of betel quid chewing and the expression of cyclooxygenase 2(COX 2), an inducible rate limiting enzyme in prostaglandin synthesis, has been documented to indicate that areca nut ingredients were involved in the pathogenesis of oral submucous fibrosis and oral cancer [38].

Our study indicates that exposure of AN and SG extracts in mice leads to a substantial increase in oxidative stress in liver (Table 6). The lowest dose $(20 \mathrm{mg} / \mathrm{kg} \mathrm{BW})$ and the middle dose $(50 \mathrm{mg} / \mathrm{kg} \mathrm{BW})$ of AN was not able to induced LPO significantly as compare to the untreated control. However, SG and AN+SG extracts show a significant increase at $(\mathrm{p}<0.001)$ in LPO compared to the untreated control (Table 6). Liver is the primary detoxifying organ of the body. Lipid peroxidation has been established as a major mechanism of cellular injury in many biological systems of plant and animal origin. The mechanism involves a process whereby unsaturated lipids are oxidized to form additional radical species as well as toxic by-products that can be harmful to the host system. Polyunsaturated lipids are especially susceptible to this type of damage when in an oxidizing environment and they can react to form lipid peroxides. Lipid peroxides are themselves unstable, and undergo additional decomposition to form a complex series of compounds including reactive carbonyl compounds. Polyunsaturated fatty acids peroxides further react to form malonaldehyde (MDA). MDA can be found in most biological samples including tissues, serum, plasma, and urine, as a result of lipid peroxidation, and has become one of the most widely reported analytes for the purpose of estimating oxidative stress effects on lipids. Extensive toxicological investigations have now established that increase in lipid peroxidation, actually denotes cytotoxicity and cellular dysfunction. Sadagura which is a very popular smokeless tobacco preparation is consumed whole day by keeping inside mouth and chewing simultaneously along with areca nut, in doing so whole oral cavity is exposed. The buccal epithelial cells are continuously exposing with test substances in actual subjects. In addition some individual may also add lime along with AN and SG. Addition of lime increased alkaline condition in the target site and is likely to generate free radicals in combination with the polyphenols [39]. SG and AN extract treated mice were showing hepatotoxicity. In addition, arecoline also caused depression of antioxidants, i.e., superoxide dismutase (SOD), catalase, reduced glutathione (GSH) and glutathione S-transferase (GST) [40].

Thus, our findings provide a strong point that areca nut and tobacco combination chewing habit in human population constitute a high risk group for development of oral cancer, precancerous and cancerous lesions as well as different forms of malignancies. Further SG has the potential to induce genotoxicity as well as cytotoxicity in the exposed human population. Present findings indicate that SG is harmful in inducing genotoxicity and more harmful when consume along with areca nut. The alkaloids of tobacco like nicotine present in sadagura may act synergistically in the pathogenesis of oral mucosal lesions with arecoline major alkaloid of areca nut in quid chewers in combination. Our results may partly explain why patients who combined the habits of areca quid chewing and smokeless tobacco sadagura addition and/or smoking are at greater risk of contracting oral cancer. Result of previous study also demonstrated that sadagura consumed as a single agent or in combination with betel quid, leads to a significant induction of cytogenetic damage in the buccal epithelial cells of habituates. This may be the primary reason behind maximum reported cases of oral cancer in India. Further studies becomes necessary to find out the contribution of various betel quid constituents, including tobacco, role of areca nut alkaloids as well as various metabolites formed inside our body, also the salivary reaction products, in betel quid induced carcinogenesis in oral epithelial cells of human.

FUNDING

Department of Science and Technology grant to SG and UGC for providing Junior Research Fellowship to SH.

\section{ACKNOWLEDGEMENTS}

We are thankful to the local people of Irongmara, Silchar (Southern part of Assam) North-East India for providing information about preparation as well as consumption of Sadagura. Dr. Mehnaz Majumdar of Department of Life Sciences and Bioinformatics, Assam University is gratefully acknowledged. 
Table1

Table showing sadagura extract, areca nut extract and areca nut with sadagura extract dose, route of administration and exposure period.

\begin{tabular}{|c|c|c|c|c|c|}
\hline \multirow[t]{2}{*}{ Extract Name } & \multicolumn{3}{|l|}{ Dose } & \multirow[t]{2}{*}{ Route } & \multirow{2}{*}{$\begin{array}{l}\text { Scoring } \\
\text { Time }(\mathrm{h})\end{array}$} \\
\hline & LOW & MIDDLE & HIGH & & \\
\hline Areca nut extract & $\begin{array}{l}\text { (AN1) } \\
20 \mathrm{mg} / \mathrm{kg} \text { bw x } \\
5 \text { days }\end{array}$ & $\begin{array}{l}\text { (AN2) } \\
50 \mathrm{mg} / \mathrm{kg} \text { bw x } \\
5 \text { days }\end{array}$ & $\begin{array}{l}(\mathrm{AN} 3) \\
80 \mathrm{mg} / \mathrm{kg} \text { bw x } \\
5 \text { days }\end{array}$ & p.o. & $\begin{array}{l}24 \\
48\end{array}$ \\
\hline Sadagura extract & $\begin{array}{l}(\mathrm{SG} 1) \\
20 \mathrm{mg} / \mathrm{kg} \text { bw x } \\
5 \text { days }\end{array}$ & $\begin{array}{l}(\mathrm{SG} 2) \\
50 \mathrm{mg} / \mathrm{kg} \text { bw x } \\
5 \text { days }\end{array}$ & $\begin{array}{l}(\mathrm{SG} 3) \\
80 \mathrm{mg} / \mathrm{kg} \text { bw x } \\
5 \text { days }\end{array}$ & p.o. & $\begin{array}{l}24 \\
48\end{array}$ \\
\hline $\begin{array}{l}\text { Areca nut with } \\
\text { sadagura extract }\end{array}$ & $\begin{array}{l}(\mathrm{AN}+\mathrm{SG} 1) \\
20 \mathrm{mg} / \mathrm{kg} \text { bw x } \\
5 \text { days }\end{array}$ & $\begin{array}{l}(\mathrm{AN}+\mathrm{SG} 2) \\
50 \mathrm{mg} / \mathrm{kg} \text { bw x } \\
5 \text { days }\end{array}$ & $\begin{array}{l}(\mathrm{AN}+\mathrm{SG} 3) \\
80 \mathrm{mg} / \mathrm{kg} \text { bw x } \\
5 \text { days }\end{array}$ & p.o. & $\begin{array}{l}24 \\
48\end{array}$ \\
\hline
\end{tabular}

Table 2

Frequency of chromosomal aberrations in the bone marrow cells of mice induced by SG with or without AN extracts at 24 hour of treatment.

\begin{tabular}{|c|c|c|c|c|c|c|c|c|c|c|c|c|c|}
\hline \multirow[b]{2}{*}{ 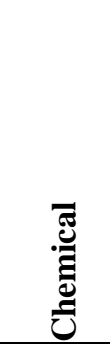 } & \multirow[b]{2}{*}{$\stackrel{\mathscr{O}}{\ddot{0}}$} & \multirow[b]{2}{*}{ 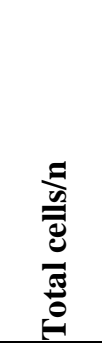 } & \multirow{2}{*}{$\begin{array}{l}\% \\
\text { Aberrant } \\
\text { cells } \\
\text { mean } \pm \text { S.E }\end{array}$} & \multirow{2}{*}{$\begin{array}{l}\% \\
\text { Mitotic } \\
\text { Index } \\
(\text { mean } \pm \text { S.E) }\end{array}$} & \multicolumn{2}{|c|}{ Chromatid } & \multicolumn{2}{|c|}{$\begin{array}{l}\text { Isochromati } \\
\text { d }\end{array}$} & \multirow[b]{2}{*}{$\underset{x}{ن}$} & \multirow[b]{2}{*}{$\bigodot_{\mathscr{\Omega}}$} & \multirow[b]{2}{*}{$\underline{\underline{\underline{u}}}$} & \multirow{2}{*}{$\begin{array}{l}\% \\
\text { Aberration } \\
\text { S } \\
\text { mean } \pm \text { S.E } \\
\text { (including } \\
\text { gaps) }\end{array}$} & \multirow{2}{*}{$\begin{array}{l}\% \\
\text { Aberrations } \\
\text { mean } \pm \text { S.E } \\
\text { (excluding gaps) }\end{array}$} \\
\hline & & & & & 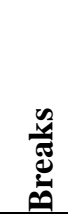 & 气̊. & ֻี & 气 & & & & & \\
\hline Con & - & $301 / 3$ & $2.99 \pm 0.51$ & $1.86 \pm 0.05$ & 0 & 2 & 0 & 9 & 3 & 0 & 4 & $5.97 \pm 0.49$ & $2.32 \pm 0.28$ \\
\hline MMC & i.p. & $300 / 3$ & $28.33 \pm 0.78$ & $0.90 \pm 0.03$ & 61 & 22 & 5 & 13 & 10 & 5 & 7 & $41.00 \pm 0.51$ & $29.33 \pm 0.78$ \\
\hline AN1 & p.o & $306 / 3$ & $6.00 \pm 0.51$ & $1.63 \pm 0.10$ & 5 & 0 & 1 & 10 & 10 & 0 & 4 & $10.00 \pm 0.89$ & $6.66 \pm 0.78^{\mathrm{ab} *}$ \\
\hline AN2 & p.o & $301 / 3$ & $8.66 \pm 0.78$ & $1.40 \pm 0.05^{*}$ & 6 & 0 & 0 & 11 & 20 & 0 & 5 & $13.90 \pm 0.08$ & $10.26 \pm 0.33^{\mathrm{ac} * * *}$ \\
\hline AN3 & p.o & $303 / 3$ & $18.33 \pm 0.59$ & $1.26 \pm 0.18^{* *}$ & 15 & 3 & 13 & 15 & 25 & 0 & 5 & $25.33 \pm 0.29$ & $19.33 \pm 0.78^{\mathrm{bc} * * *}$ \\
\hline SG1 & p.o & $306 / 3$ & $5.00 \pm 0.51$ & $1.46 \pm 0.08 *$ & 8 & 7 & 2 & 13 & 4 & 0 & 3 & $12.33 \pm 0.29$ & $5.66 \pm 0.59^{\mathrm{a} b} *$ \\
\hline SG2 & p.o & $301 / 3$ & $10.33 \pm 0.78$ & $1.43 \pm 0.05^{*}$ & 4 & 1 & 0 & 10 & 23 & 0 & 7 & $15.00 \pm 0.51$ & $11.33 \pm 0.29^{\mathrm{a} \mathrm{c} * * *}$ \\
\hline SG3 & p.o & $303 / 3$ & $13.66 \pm 0.59$ & $1.23 \pm 0.05 * * *$ & 12 & 6 & 5 & 9 & 21 & 1 & 7 & $20.33 \pm 0.78$ & $15.33 \pm 0.78^{\mathrm{bc} * * *}$ \\
\hline $\begin{array}{l}\mathbf{A N}+\mathbf{S} \\
\mathbf{G 1}\end{array}$ & p.o & $306 / 3$ & $7.66 \pm 0.59$ & $1.30 \pm 0.10 * *$ & 9 & 1 & 5 & 8 & 8 & 0 & 5 & $12.00 \pm 0.08$ & $9.00 \pm 0.51^{\mathrm{a} * * *}$ \\
\hline $\begin{array}{l}\mathbf{A N}+\mathbf{S} \\
\mathbf{G 2} \\
\end{array}$ & p.o & $301 / 3$ & $9.00 \pm 0.51$ & $1.26 \pm 0.06 * *$ & 4 & 3 & 2 & 9 & 17 & 0 & 10 & $15.00 \pm 0.05$ & $11.00 \pm 0.89^{\mathrm{b} * * *}$ \\
\hline $\begin{array}{l}\mathrm{AN}+\mathrm{S} \\
\mathrm{G3} \\
\end{array}$ & p.o & $303 / 3$ & $21.33 \pm 0.78$ & $1.20 \pm 0.03 * * *$ & 19 & 0 & 18 & 9 & 26 & 0 & 10 & $27.33 \pm 0.65$ & $24.33 \pm 0.78^{\mathrm{a} b * * *}$ \\
\hline
\end{tabular}

BW: body weight; Con: Control group animals treated with solvent (Dimethyl sulphoxide) vehicle; MMC: Mitomycin C; Areca nut: AN1 (lower dose $=20 \mathrm{mg} / \mathrm{kg} \mathrm{bw}$ ), AN2 (middle dose = $50 \mathrm{mg} / \mathrm{kg} \mathrm{bw}$ ), AN3 (highest dose = $80 \mathrm{mg} / \mathrm{kg}$ bw); i.p = Intraperitoneal; 
p.o $=$ Per oral (by mouth); $\mathrm{n}=$ Total number of animals. Exc: exchanges; SCU: Sister chromatid union; R.T.: Robertsonian translocation. Groups bearing the same superscript are significantly different from each other $[\mathrm{a}=\mathrm{P}<0.05 ; \mathrm{b}, \mathrm{c}=\mathrm{P}<0.001]$; Groups bearing any of the following symbol is significantly different from control, $* \mathrm{P}<0.05 ; * * \mathrm{P}<0.01 ; * * * \mathrm{P}<0.001$.

Table 3

Frequency of chromosomal aberrations in the bone marrow cells of mice induced by SG with or without AN extract at 48 hour of treatment.

\begin{tabular}{|c|c|c|c|c|c|c|c|c|c|c|c|c|c|}
\hline \multirow{2}{*}{ 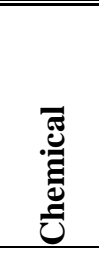 } & \multirow[b]{2}{*}{ 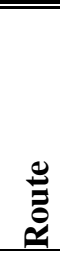 } & \multirow{2}{*}{ 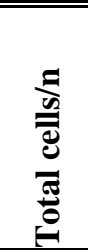 } & \multirow{2}{*}{$\begin{array}{l}\% \\
\text { Aberrant } \\
\text { cells } \\
\text { mean } \pm S . \\
\text { E }\end{array}$} & \multirow{2}{*}{$\begin{array}{l}\% \\
\text { Mitotic } \\
\text { Index } \\
(\text { mean } \pm \text { S.E) }\end{array}$} & \multicolumn{2}{|c|}{$\begin{array}{l}\text { Chromati } \\
\text { d }\end{array}$} & \multicolumn{2}{|c|}{$\begin{array}{l}\text { Isochromat } \\
\text { id }\end{array}$} & \multirow[b]{2}{*}{ 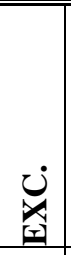 } & \multirow[b]{2}{*}{$\overbrace{\mathscr{D}}$} & \multirow[b]{2}{*}{ 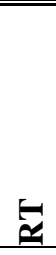 } & \multirow{2}{*}{$\begin{array}{l}\% \\
\text { Aberratio } \\
\text { ns } \\
\text { mean } \pm \text { S.E } \\
\text { (including } \\
\text { gaps) } \\
\end{array}$} & \multirow{2}{*}{$\begin{array}{l}\% \\
\text { Aberrations } \\
\text { mean } \pm \text { S.E } \\
\text { (excluding gaps) }\end{array}$} \\
\hline & & & & & 苋 & 啇 & 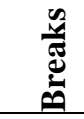 & స్ & & & & & \\
\hline Con & - & $\begin{array}{l}301 / \\
3\end{array}$ & $2.98 \pm 0.50$ & $1.83 \pm 0.03$ & 0 & 2 & 4 & 5 & 2 & 0 & 2 & $4.98 \pm 0.52$ & $2.65 \pm 0.58$ \\
\hline MMC & i.p & $\begin{array}{l}300 / \\
3\end{array}$ & $\begin{array}{l}23.66 \pm 0.7 \\
8\end{array}$ & $0.93 \pm 0.03$ & 34 & 26 & 19 & 17 & $\begin{array}{l}1 \\
2\end{array}$ & 5 & 3 & $38.66 \pm 0.78$ & $24.33 \pm 0.78$ \\
\hline AN1 & p.o & $\begin{array}{l}306 / \\
3\end{array}$ & $5.66 \pm 0.78$ & $1.66 \pm 0.08$ & 5 & 7 & 1 & 9 & 5 & 0 & 4 & $10.33 \pm 0.81$ & $5.00 \pm 0.51^{\mathrm{a} b}$ \\
\hline AN2 & p.o & $\begin{array}{l}301 / \\
3\end{array}$ & $8.33 \pm 0.59$ & $1.40 \pm 0.05^{*}$ & 7 & 5 & 3 & 10 & $\begin{array}{l}1 \\
8\end{array}$ & 0 & 4 & $15.66 \pm 0.79$ & $10.66 \pm 0.79^{\mathrm{ac} * * * *}$ \\
\hline AN3 & p.o & $\begin{array}{l}303 / \\
3 \\
\end{array}$ & $\begin{array}{l}17.00 \pm 0.8 \\
9\end{array}$ & $1.33 \pm 0.13 *$ & 16 & 3 & 10 & 15 & $\begin{array}{l}2 \\
2 \\
\end{array}$ & 1 & 5 & $24.00 \pm 0.51$ & $18.00 \pm 0.89^{\mathrm{bc} * * *}$ \\
\hline SG1 & p.o & $\begin{array}{l}306 / \\
3\end{array}$ & $3.98 \pm 0.01$ & $1.50 \pm 0.08 *$ & 5 & 8 & 0 & 13 & 5 & 0 & 3 & $11.30 \pm 0.54$ & $4.32 \pm 0.30^{\mathrm{ab}}$ \\
\hline SG2 & p.o & $\begin{array}{l}301 / \\
3\end{array}$ & $8.00 \pm 0.51$ & $1.40 \pm 0.05^{* *}$ & 6 & 3 & 0 & 14 & $\begin{array}{l}1 \\
7 \\
\end{array}$ & 0 & 5 & $15.00 \pm 0.05$ & $9.33 \pm 0.98$ a c *** \\
\hline SG3 & p.o & $\begin{array}{l}303 / \\
3 \\
\end{array}$ & $\begin{array}{l}10.00 \pm 0.5 \\
1\end{array}$ & $\begin{array}{l}1.33 \pm 0.05 * * \\
*\end{array}$ & 10 & 9 & 5 & 20 & $\begin{array}{l}1 \\
8\end{array}$ & 1 & 4 & $22.33 \pm 0.30$ & $\begin{array}{l}12.67 \pm 0.78 \quad \mathrm{~b} \\
* * *\end{array}$ \\
\hline $\begin{array}{l}\text { AN+S } \\
\text { G1 }\end{array}$ & p.o & $\begin{array}{l}306 / \\
3\end{array}$ & $7.66 \pm 0.78$ & $1.33 \pm 0.14 *$ & 8 & 3 & 5 & 9 & 6 & 0 & 5 & $12.00 \pm 0.60$ & $8.00 \pm 0.89$ a $* *$ \\
\hline $\begin{array}{l}\mathrm{AN}+\mathrm{S} \\
\mathrm{G2}\end{array}$ & p.o & $\begin{array}{l}301 / \\
3\end{array}$ & $9.33 \pm 0.29$ & $1.30 \pm 0.06^{* *}$ & 7 & 4 & 0 & 19 & $\begin{array}{l}1 \\
5\end{array}$ & 0 & 8 & $17.67 \pm 0.79$ & $10.00 \pm 0.48^{\mathrm{b} * * *}$ \\
\hline $\begin{array}{l}\text { AN+S } \\
\text { G3 }\end{array}$ & p.o & $\begin{array}{l}303 / \\
3\end{array}$ & $\begin{array}{l}20.00 \pm 0.5 \\
1\end{array}$ & $1.20 \pm 0.05^{* *}$ & 16 & 5 & 16 & 10 & $\begin{array}{l}2 \\
4\end{array}$ & 2 & 9 & $27.33 \pm 0.60$ & $22.33 \pm 0.78^{\mathrm{a} b * * *}$ \\
\hline
\end{tabular}

bw: body weight; Con: Control group animals treated with solvent (Dimethyl sulphoxide) vehicle; MMC: Mitomycin C; Areca nut: AN1 (lower dose $=20 \mathrm{mg} / \mathrm{kg} \mathrm{bw}$ ), AN2 (middle dose $=50 \mathrm{mg} / \mathrm{kg} \mathrm{bw}$ ), AN3 (highest dose $=80 \mathrm{mg} / \mathrm{kg}$ bw); i.p = Intraperitoneal; p.o $=$ Per oral (by mouth); $\mathrm{n}=$ Total number of animals. Exc: exchanges; SCU: Sister chromatid union; R.T.: Robertsonian translocation. Groups bearing the same superscript are significantly different from each other $[\mathrm{a}=\mathrm{P}<0.01 ; \mathrm{b}, \mathrm{c}=\mathrm{P}<0.001]$; Groups bearing any of the following symbol is significantly different from control, $* \mathrm{P}<0.05 ; * * \mathrm{P}<0.01 ; * * * \mathrm{P}<0.001$.

Table 4

Frequency of micronucleus (MN) in the bone marrow cells of mice induced by SG with or without AN extracts at 24 and 48 hours of exposure period.

\begin{tabular}{|c|c|c|c|c|c|c|c|c|c|}
\hline \multirow[b]{2}{*}{ Treatment } & \multirow[b]{2}{*}{ 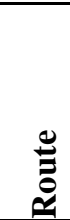 } & \multicolumn{4}{|l|}{ At $24 \mathrm{~h}$} & \multicolumn{4}{|l|}{$\overline{A t} 48 \mathrm{~h}$} \\
\hline & & $\begin{array}{l}\text { Total } \\
\text { PCE/n }\end{array}$ & $\begin{array}{l}\text { Total } \\
\text { NCE }\end{array}$ & $\begin{array}{l}\% \text { PCEs } \\
\text { with MN } \\
(\text { mean } \pm \text { S.D) }\end{array}$ & $\begin{array}{l}\text { PCE/NCE } \\
(\text { mean } \pm \text { S.D })\end{array}$ & $\begin{array}{l}\text { Total } \\
\text { PCE/n }\end{array}$ & $\begin{array}{l}\text { Total } \\
\text { NCE }\end{array}$ & $\begin{array}{l}\text { \% PCEs } \\
\text { with } \\
(\text { mean } \pm \text { S.D) }\end{array}$ & $\begin{array}{l}\text { PCE/NCE } \\
(\text { mean } \pm \text { S.D })\end{array}$ \\
\hline Con & - & $6004 / 3$ & 4112 & $1.31 \pm 0.25$ & $1.49 \pm 0.33$ & $6000 / 3$ & 4196 & $1.30 \pm 0.25$ & $1.46 \pm 0.24$ \\
\hline MMC & i.p & $6000 / 3$ & 7317 & $7.05 \pm 0.82$ & $0.82 \pm 0.06$ & $6000 / 3$ & 6742 & $6.98 \pm 1.56$ & $0.89 \pm 0.06$ \\
\hline
\end{tabular}




\begin{tabular}{|l|l|l|l|l|l|l|l|l|l|}
\hline AN1 & p.o & $6000 / 3$ & 3636 & $2.11 \pm 0.19$ & $1.65 \pm 0.18$ & $6002 / 3$ & 3751 & $2.15 \pm 0.25$ & $1.67 \pm 0.37$ \\
\hline AN2 & p.o & $6004 / 3$ & 4619 & $2.48 \pm 0.51$ & $1.30 \pm 0.26$ & $6000 / 3$ & 4138 & $2.19 \pm 0.55$ & $1.44 \pm 0.11$ \\
\hline AN3 & p.o & $6000 / 3$ & 4688 & $3.79 \pm 0.69^{* *}$ & $1.31 \pm 0.22$ & $6000 / 3$ & 4511 & $3.00 \pm 0.68^{*}$ & $1.35 \pm 0.18$ \\
\hline SG1 & p.o & $6010 / 3$ & 4007 & $1.65 \pm 0.29$ & $1.58 \pm 0.37$ & $6018 / 3$ & 4066 & $2.08 \pm 0.37^{*}$ & $1.48 \pm 0.08$ \\
\hline SG2 & p.o & $6000 / 3$ & 4225 & $2.19 \pm 0.82$ & $1.47 \pm 0.29$ & $6020 / 3$ & 4152 & $2.89 \pm 0.08^{* * *}$ & $1.45 \pm 0.09$ \\
\hline SG3 & p.o & $6000 / 3$ & 4380 & $3.49 \pm 0.52^{* *}$ & $1.41 \pm 0.27$ & $6000 / 3$ & 4348 & $3.22 \pm 0.15^{* * *}$ & $1.41 \pm 0.21$ \\
\hline AN+SG1 & p.o & $6050 / 3$ & 3601 & $3.36 \pm 0.76^{*}$ & $1.69 \pm 0.16$ & $6010 / 3$ & 4007 & $3.18 \pm 0.74$ & $1.51 \pm 0.17$ \\
\hline AN+SG2 & p.o & $6000 / 3$ & 4615 & $3.19 \pm 0.59^{*}$ & $1.30 \pm 0.06$ & $6000 / 3$ & 4138 & $3.83 \pm 0.80^{*}$ & $1.46 \pm 0.16$ \\
\hline AN+SG3 & p.o & $6000 / 3$ & 5085 & $4.59 \pm 0.55^{* *}$ & $1.18 \pm 0.06$ & $6000 / 3$ & 4348 & $4.19 \pm 0.93^{*}$ & $1.42 \pm 0.27$ \\
\hline \hline
\end{tabular}

Con: Control group animals treated with solvent (Dimethyl sulphoxide) vehicle; MMC: Mitomycin C; Areca nut: AN1 (lower dose = $20 \mathrm{mg} / \mathrm{kg} \mathrm{bw}$ ), AN2 (middle dose $=50 \mathrm{mg} / \mathrm{kg} \mathrm{bw}$ ), AN3 (highest dose $=80 \mathrm{mg} / \mathrm{kg} \mathrm{bw}$ ); i.p = Intraperitoneal; p.o = Per oral (by mouth); $\mathrm{n}=$ Total number of animals. PCE $=$ Polychromatic Erythrocytes; NCE $=$ Normochromatic Erythrocytes; MN $=$ Micronucleus. Groups bearing any of the following symbol is significantly different from control, * $\mathrm{P}<0.05 ; * * \mathrm{P}<0.01$.

Table 5

Incidence of sperm head abnormality (SHA) induced by SG with or without AN extracts and total sperm count in mice.

\begin{tabular}{|c|c|c|c|c|c|c|c|c|c|c|c|c|c|c|c|c|c|}
\hline \multirow[b]{2}{*}{ 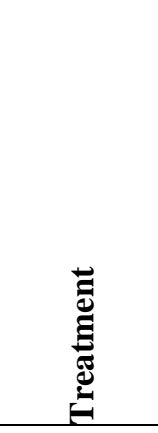 } & \multirow[b]{2}{*}{ 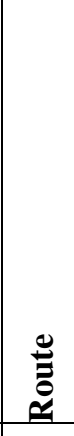 } & \multirow{2}{*}{ 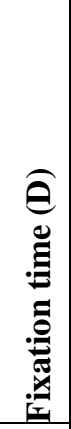 } & \multirow{2}{*}{ 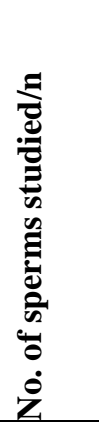 } & \multirow{2}{*}{ 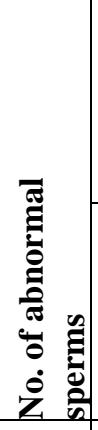 } & \multicolumn{11}{|c|}{ Types of abnormalities studied } & \multirow{2}{*}{$\begin{array}{l}\% \\
\text { Abnormal } \\
\text { sperms } \\
(\text { mean } \pm \text { S.D) }\end{array}$} & \multirow{2}{*}{$\begin{array}{l}\text { Total sperm } \\
\text { count/epididymis } \\
(\text { mean } \pm \text { S.D })\end{array}$} \\
\hline & & & & & $\frac{2}{0}$ & 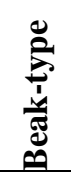 & 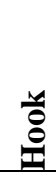 & 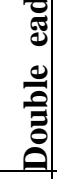 & | & 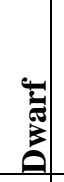 & : & 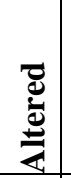 & 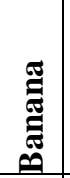 & : & 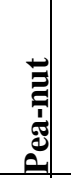 & & \\
\hline Con & - & $\begin{array}{l}3 \\
5\end{array}$ & $\begin{array}{l}3007 / \\
3\end{array}$ & 68 & 26 & 16 & 4 & 1 & 2 & 0 & 2 & $\begin{array}{l}1 \\
5\end{array}$ & 2 & 0 & 0 & $2.26 \pm 0.49$ & $34.30 \times 10^{6} \pm 0.19$ \\
\hline MMC & i.p & $\begin{array}{l}3 \\
5\end{array}$ & $\begin{array}{l}3000 / \\
3\end{array}$ & 431 & $\begin{array}{l}19 \\
5\end{array}$ & 64 & $\begin{array}{l}1 \\
9\end{array}$ & 7 & $\begin{array}{l}2 \\
8\end{array}$ & 9 & 6 & $\begin{array}{l}7 \\
2\end{array}$ & $\begin{array}{l}2 \\
3\end{array}$ & 6 & 2 & $14.36 \pm 0.05$ & $12.55 \times 10^{6} \pm 1.44$ \\
\hline AN1 & p.o & $\begin{array}{l}3 \\
5\end{array}$ & $\begin{array}{l}3000 / \\
3\end{array}$ & 85 & 45 & 12 & 2 & 0 & 9 & 1 & 1 & 8 & 6 & 1 & 0 & $2.83 \pm 0.13^{\mathrm{a}}$ & $\underset{\substack{29.18 \\
b * * *}}{ } \times 10^{6} \pm 0.96^{\mathrm{a}}$ \\
\hline AN2 & p.o & $\begin{array}{l}3 \\
5\end{array}$ & $\begin{array}{l}3004 / \\
3\end{array}$ & 187 & 99 & 29 & 8 & 1 & $\begin{array}{l}1 \\
0\end{array}$ & 0 & 3 & $\begin{array}{l}2 \\
4\end{array}$ & $\begin{array}{l}1 \\
0\end{array}$ & 2 & 1 & $6.23 \pm 1.61^{\mathrm{b} *}$ & $\begin{array}{l}24.67 \\
\substack{c * * * *\\
}\end{array}$ \\
\hline AN3 & p.o & \begin{tabular}{|l|}
3 \\
5 \\
\end{tabular} & $\begin{array}{l}3000 / \\
3 \\
\end{array}$ & 305 & $\begin{array}{l}12 \\
7 \\
\end{array}$ & 49 & $\begin{array}{l}1 \\
0\end{array}$ & 2 & $\begin{array}{l}2 \\
1 \\
\end{array}$ & 2 & 6 & $\begin{array}{l}5 \\
4 \\
\end{array}$ & $\begin{array}{l}2 \\
6 \\
\end{array}$ & 5 & 3 & $\begin{array}{lll}10.16 \pm & 1.44 & \\
b * * * & & \\
\end{array}$ & $\begin{array}{l}19.50 \\
\mathrm{c} * * *\end{array}$ \\
\hline SG1 & p.o & $\begin{array}{l}3 \\
5 \\
\end{array}$ & $\begin{array}{l}3000 / \\
3\end{array}$ & 134 & 67 & 18 & 6 & 3 & 8 & 1 & 2 & $\begin{array}{l}1 \\
9 \\
\end{array}$ & 9 & 1 & 0 & $4.46 \pm 0.67^{\mathrm{a}}$ & $30.36 \times 10^{6} \pm 1.62^{\mathrm{a} *}$ \\
\hline SG2 & p.o & $\begin{array}{l}3 \\
5 \\
\end{array}$ & $\begin{array}{l}3200 / \\
3\end{array}$ & 248 & $\begin{array}{l}12 \\
6 \\
\end{array}$ & 37 & 8 & 4 & $\begin{array}{l}1 \\
3\end{array}$ & 0 & 5 & $\begin{array}{l}4 \\
3 \\
\end{array}$ & 9 & 3 & 0 & $7.76 \pm 0.41^{\mathrm{b} * * *}$ & $28.50 \times 10^{6} \pm 0.93^{\mathrm{b} * *}$ \\
\hline SG3 & p.o & \begin{tabular}{|l}
3 \\
5 \\
\end{tabular} & $\begin{array}{l}3100 / \\
3\end{array}$ & 353 & $\begin{array}{l}15 \\
7\end{array}$ & 53 & $\begin{array}{l}1 \\
7\end{array}$ & 2 & $\begin{array}{l}2 \\
3\end{array}$ & 5 & 6 & $\begin{array}{l}6 \\
7\end{array}$ & $\begin{array}{l}1 \\
8\end{array}$ & 4 & 1 & $\begin{array}{l}11.40 \pm \\
\mathrm{b} * * *\end{array}$ & $\underset{b * * *}{20.00 \times 10^{6} \pm 0.89}$ \\
\hline $\mathrm{AN}+\mathrm{SG} 1$ & p.o & $\begin{array}{l}3 \\
5\end{array}$ & $\begin{array}{l}3000 / \\
3\end{array}$ & 150 & 66 & 17 & $\begin{array}{l}1 \\
0\end{array}$ & 2 & $\begin{array}{l}1 \\
1\end{array}$ & 2 & 2 & $\begin{array}{l}2 \\
4\end{array}$ & $\begin{array}{l}1 \\
0\end{array}$ & 4 & 2 & $5.00 \pm 0.44^{\mathrm{ab}}$ & $\begin{array}{l}26.00 \times 10^{6} \pm 0.89^{a} \\
\text { b**** }\end{array}$ \\
\hline $\mathrm{AN}+\mathrm{SG} 2$ & p.o & $\begin{array}{l}3 \\
5\end{array}$ & $\begin{array}{l}3020 / \\
3\end{array}$ & 309 & $\begin{array}{l}17 \\
7\end{array}$ & 35 & 8 & 4 & $\begin{array}{l}1 \\
6\end{array}$ & 2 & 5 & $\begin{array}{l}4 \\
6\end{array}$ & $\begin{array}{l}1 \\
3\end{array}$ & 3 & 0 & $10.23 \pm 1.52^{\mathrm{a} * * *}$ & $\underset{\mathrm{c} * * *}{21.81} \times 10^{6} \pm 0.92^{\mathrm{a}}$ \\
\hline AN+SG3 & p.o & \begin{tabular}{|l|}
3 \\
5 \\
\end{tabular} & $\begin{array}{l}3000 / \\
3 \\
\end{array}$ & 404 & $\begin{array}{l}18 \\
9 \\
\end{array}$ & 59 & $\begin{array}{l}1 \\
7 \\
\end{array}$ & 5 & $\begin{array}{l}2 \\
5\end{array}$ & 5 & 8 & $\begin{array}{l}6 \\
8 \\
\end{array}$ & $\begin{array}{l}1 \\
9 \\
\end{array}$ & 5 & 4 & $13.46 \pm 1.10^{\mathrm{b} * * *}$ & $\begin{array}{l}17.98 \times 10^{6} \pm 0.76^{\mathrm{b}} \\
\text { c*** }\end{array}$ \\
\hline
\end{tabular}

Con. $=$ Control solvent vehicle was given; MMC: mitomycin C ( $2 \mathrm{mg} / \mathrm{kg} \mathrm{bw})$; Areca nut extract: AN1 = $20 \mathrm{mg} / \mathrm{kg} \mathrm{bw}$, AN2 $=50 \mathrm{mg} / \mathrm{kg}$ bw, AN3 $=80 \mathrm{mg} / \mathrm{kg}$ bw; i.p = intraperitoneal; $\mathrm{p} . \mathrm{o}=$ Per oral $($ by mouth); $\mathrm{D}=$ days; $\mathrm{n}=$ Total number of animals used.

This publication is licensed under Creative Commons Attribution CC BY. 
Groups bearing the same superscript are significantly different from each other $[\mathrm{b}=\mathrm{P}<0.05 ; \mathrm{a}=\mathrm{P}<0.01$ and $\mathrm{a}, \mathrm{b}, \mathrm{c}=\mathrm{P}<0.001] ; * \mathrm{P}<0.05$ Significantly different from control; $* * \mathrm{P}<0.01$ Significantly different from control; *** $\mathrm{P}<0.001$ Significantly different from control.

Table 6

Table showing SG with or without AN extract induced lipid peroxidation after 24 hour exposure time

\begin{tabular}{|l|l|l|l|l|}
\hline \hline \multirow{3}{*}{ Group } & $\begin{array}{l}\text { Dose } \\
(\mathbf{m g} / \mathbf{k g} \text { bw) }\end{array}$ & Route & Exposure time & n mol MDA/g wet tissue) \\
\hline Con & - & - & $24 \mathrm{~h}$ & $2.86 \pm 0.35$ \\
\hline MMC & 2 & i.p & $24 \mathrm{~h}$ & $11.41 \pm 0.61$ \\
\hline \multirow{5}{*}{ Areca nut extract } & 20 & i.p & $24 \mathrm{~h}$ & $7.45 \pm 0.97$ \\
\cline { 2 - 5 } & 50 & i.p & $24 \mathrm{~h}$ & $8.65 \pm 0.34$ \\
\cline { 2 - 5 } & 80 & i.p & $24 \mathrm{~h}$ & $10.66 \pm 0.50 * *$ \\
\hline \multirow{3}{*}{ Sadagura extract } & 20 & i.p & $24 \mathrm{~h}$ & $8.67 \pm 0.53 * *$ \\
\cline { 2 - 5 } & 50 & i.p & $24 \mathrm{~h}$ & $9.86 \pm 0.18 * * *$ \\
\cline { 2 - 5 } & 80 & i.p & $24 \mathrm{~h}$ & $11.94 \pm 0.22 * * *$ \\
\hline \multirow{3}{*}{ AN+SG extract } & 20 & i.p & $24 \mathrm{~h}$ & $10.23 \pm 0.08 * * * *$ \\
\cline { 2 - 5 } & 50 & i.p & $24 \mathrm{~h}$ & $11.57 \pm 0.30 * * *$ \\
\cline { 2 - 5 } & 80 & i.p & $24 \mathrm{~h}$ & \\
\hline \hline
\end{tabular}

Figure 1: Photograph showing the components of smokeless tobacco preparation, sadagura
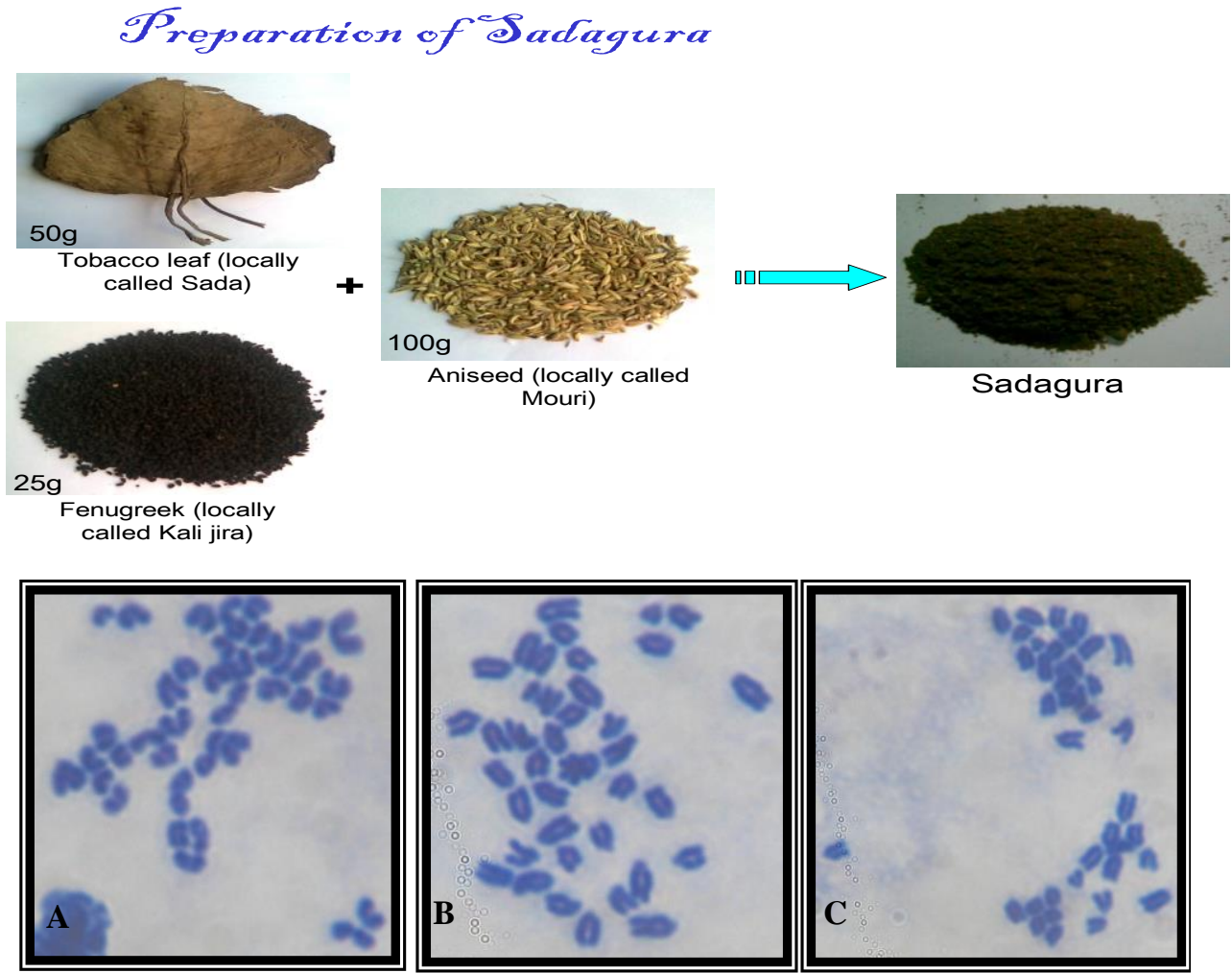

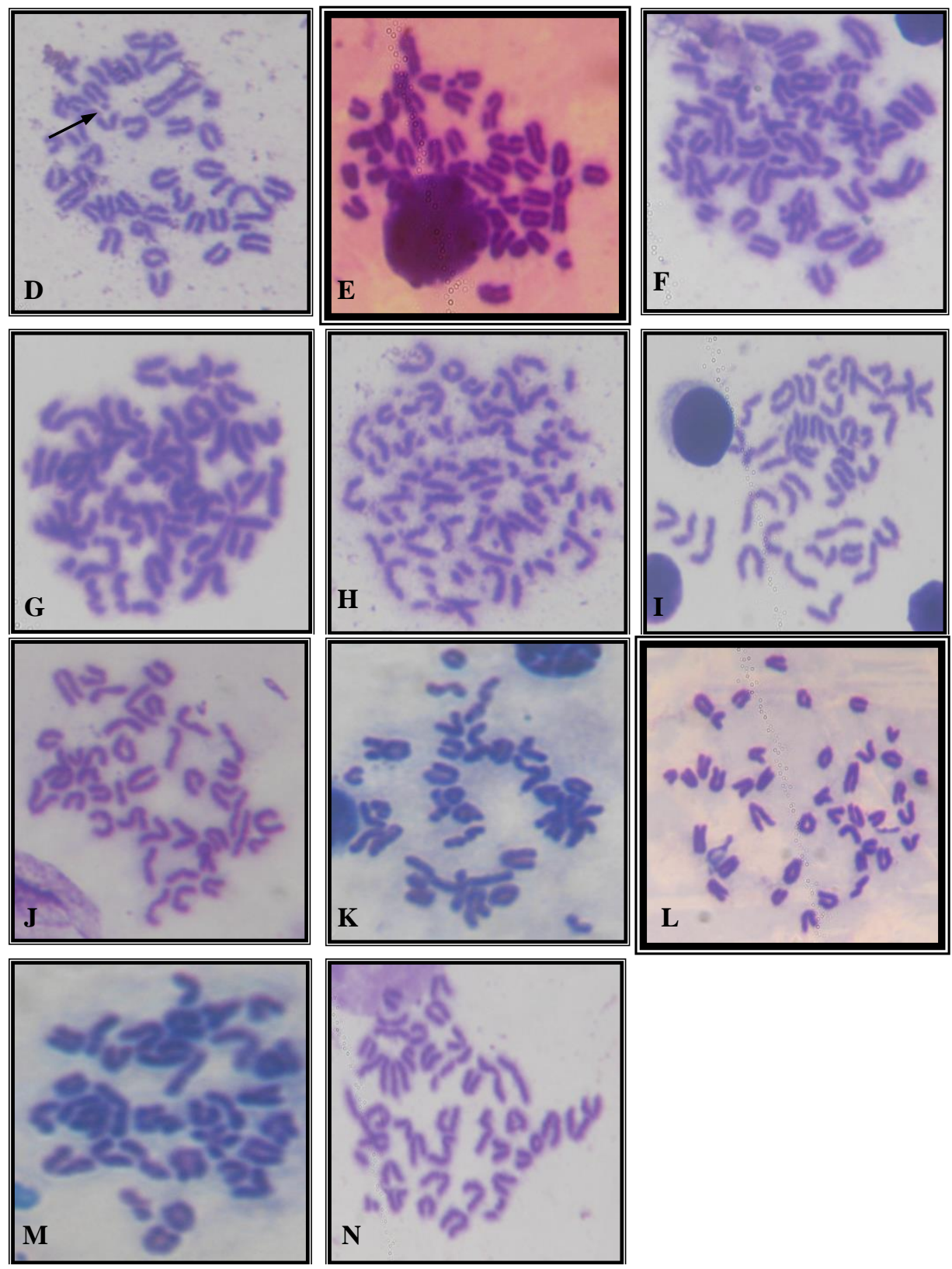


\section{Figure 2:}

Photomicrographs of murine bone marrow metaphase spreads showing different types of chromosomal aberrations induced by extracts of areca nut and sadagura alone or in combination under various treatment conditions. A, B, C: normal complement of chromosomes; D, F, G: chromatid breaks; E: chromatid gaps; H: isochromatid gap; I: terminal exchange; J: chromosome exchange; K, $\mathrm{L}$ : ring chromosome; M, N: Robertsonian translocation or centric fusion.

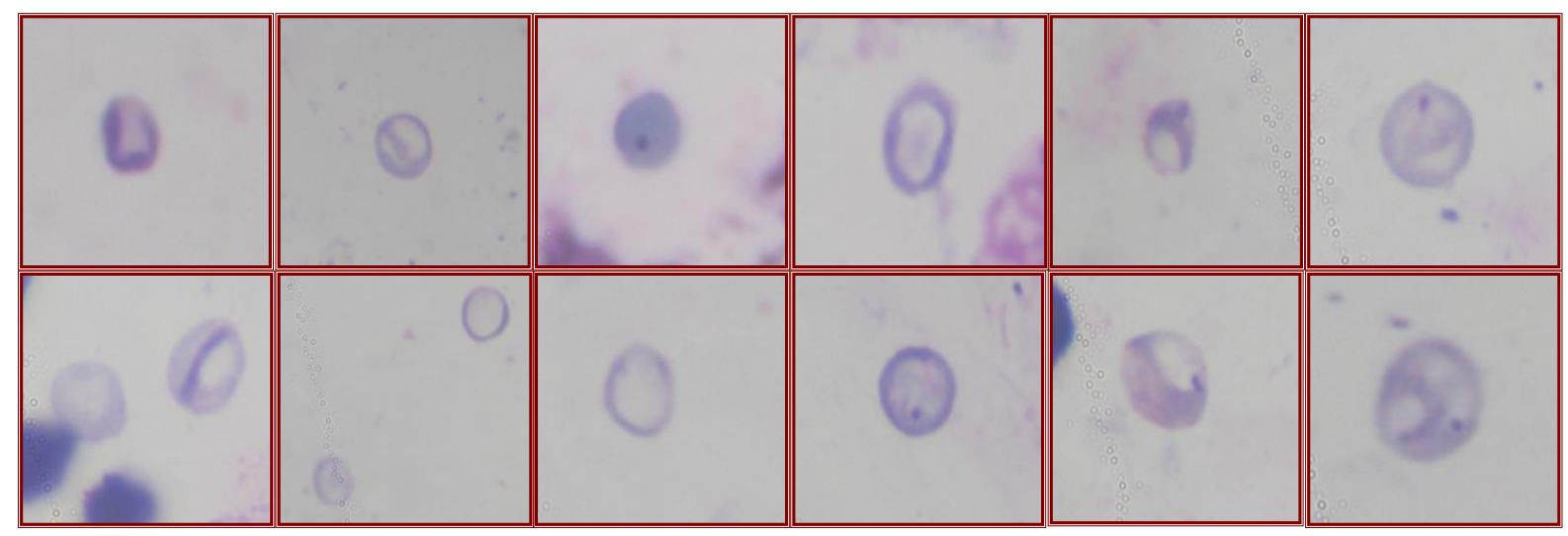

\section{Figure 3:}

Photomicrographs of murine bone marrow cells i.e., polychromatic erythrocytes and normochromatic erythrocytes, with micronucleus induced by extracts of areca nut and sadagura alone or in combination under various treatment conditions. 


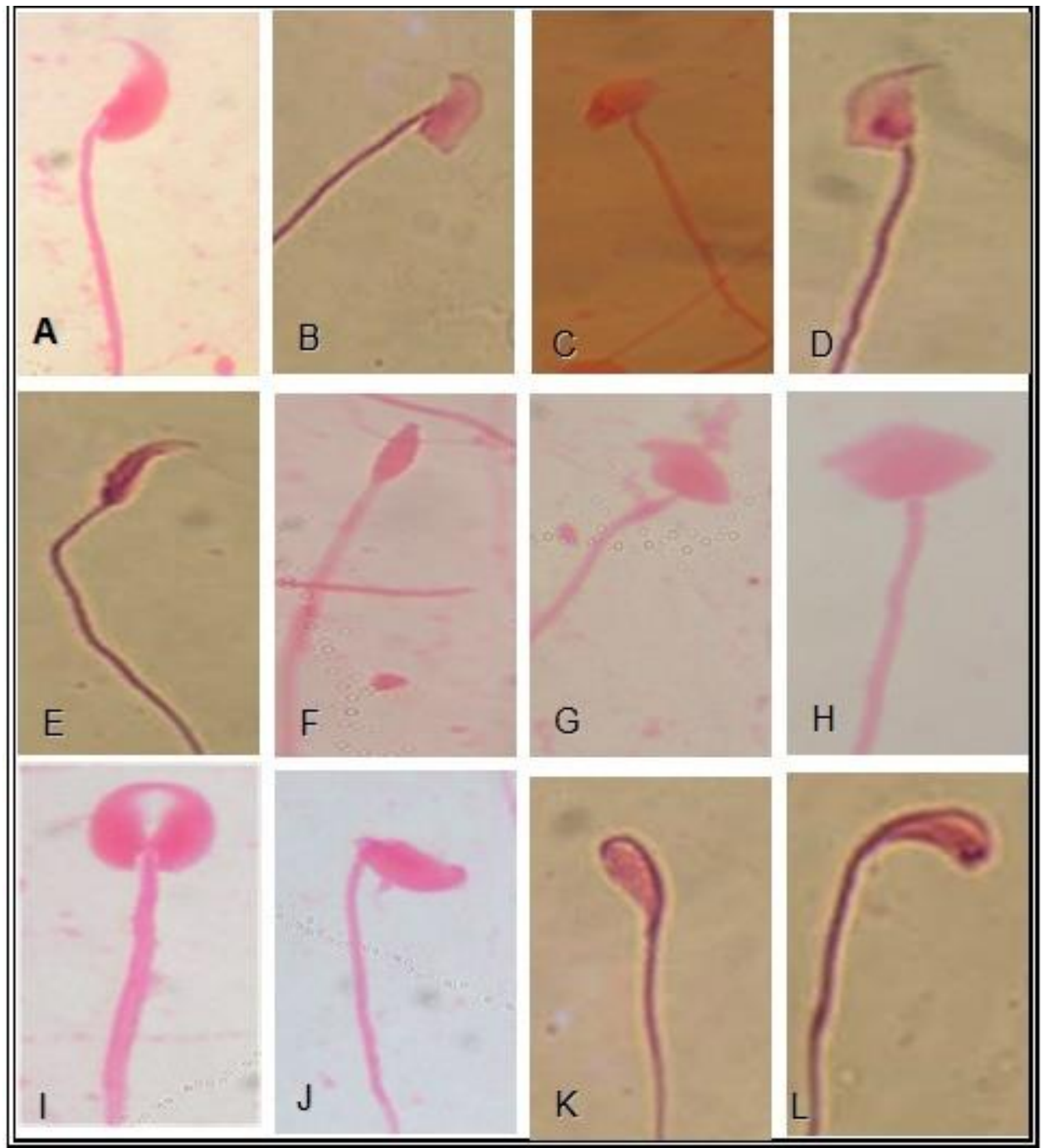

\section{Figure 4:}

Photomicrographs of murine sperms showing abnormal head morphology induced by extracts of areca nut and sadagura alone or in combination under various treatment conditions as described in the text. A: Showing normal head morphology; B, C: Amorphous type of heads; D: Triangular type of head; E, F: Pin-head type of heads; G: Hook-type head; H: Beak-type head; I: Double headed; J: Banana type head; K: Bent at projecting filament; L: Bent at cephalocaudal junction.<smiles>[NH3+]c1nc(O)cc(O)n1</smiles>

TBA<smiles>CCCC=O</smiles>

MDA<smiles>OC1=NC(=S)N=C(O)C1=CC=Cc1c(O)nc(S)nc1O</smiles>

\section{Product}

\section{Figure 5:}

The reaction of thiobarbituric acid with malondialdehyde to produce a coloured product with absorbance at 535 . 


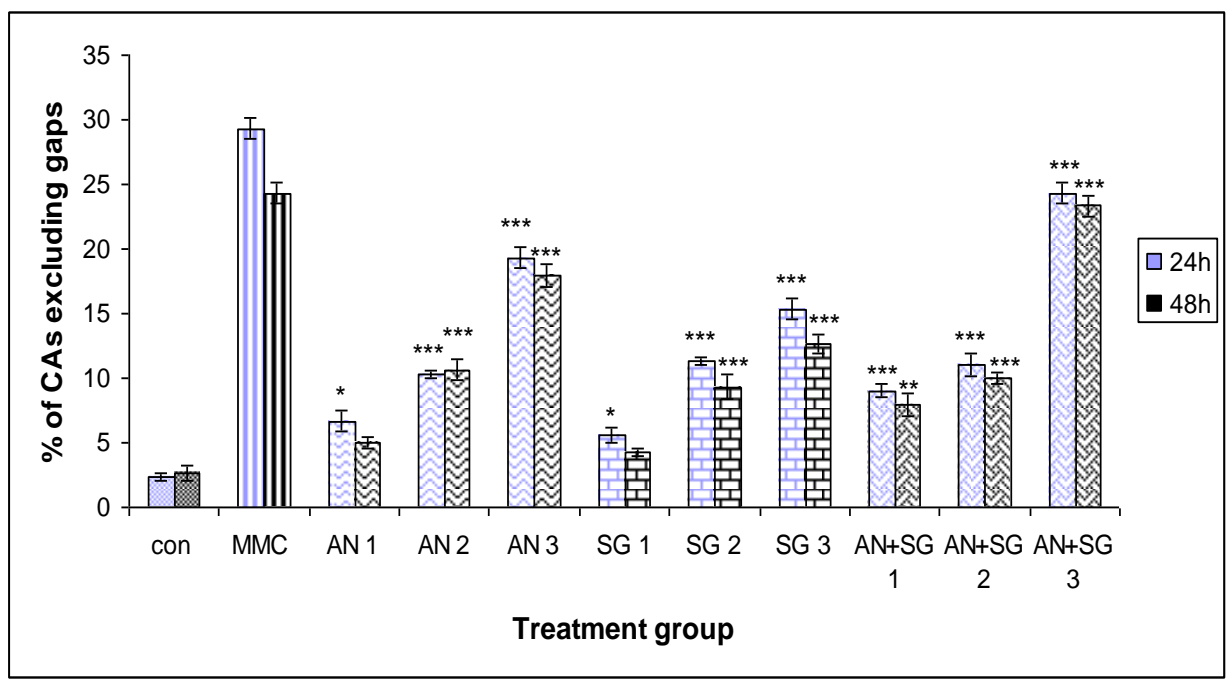

\section{Figure 6:}

Histograms showing the comparative study of the frequency of chromosome aberrations after 24 hour and 48 hour exposure in the bone marrow cells following areca nut and sadagura extract alone or in combination treatment. Con $=$ Control group animals treated with solvent (DMSO) vehicle; MMC: Mitomycin C; AN1, AN2, AN3 = Areca nut extract (20, 50 and $80 \mathrm{mg} / \mathrm{kg}$ bw respectively); SG1, SG2, SG3 = Sadagura extract (20,50 and $80 \mathrm{mg} / \mathrm{kg}$ bw respectively); AN+SG1, AN+SG2, AN+SG3 = Areca nut with sadagura extract $\left(20,50\right.$ and $80 \mathrm{mg} / \mathrm{kg}$ bw respectively). ${ }^{*}=\mathrm{P}<0.05, * *=\mathrm{P}<0.01$ and $* * *=\mathrm{P}<0.001$ significantly different from control.

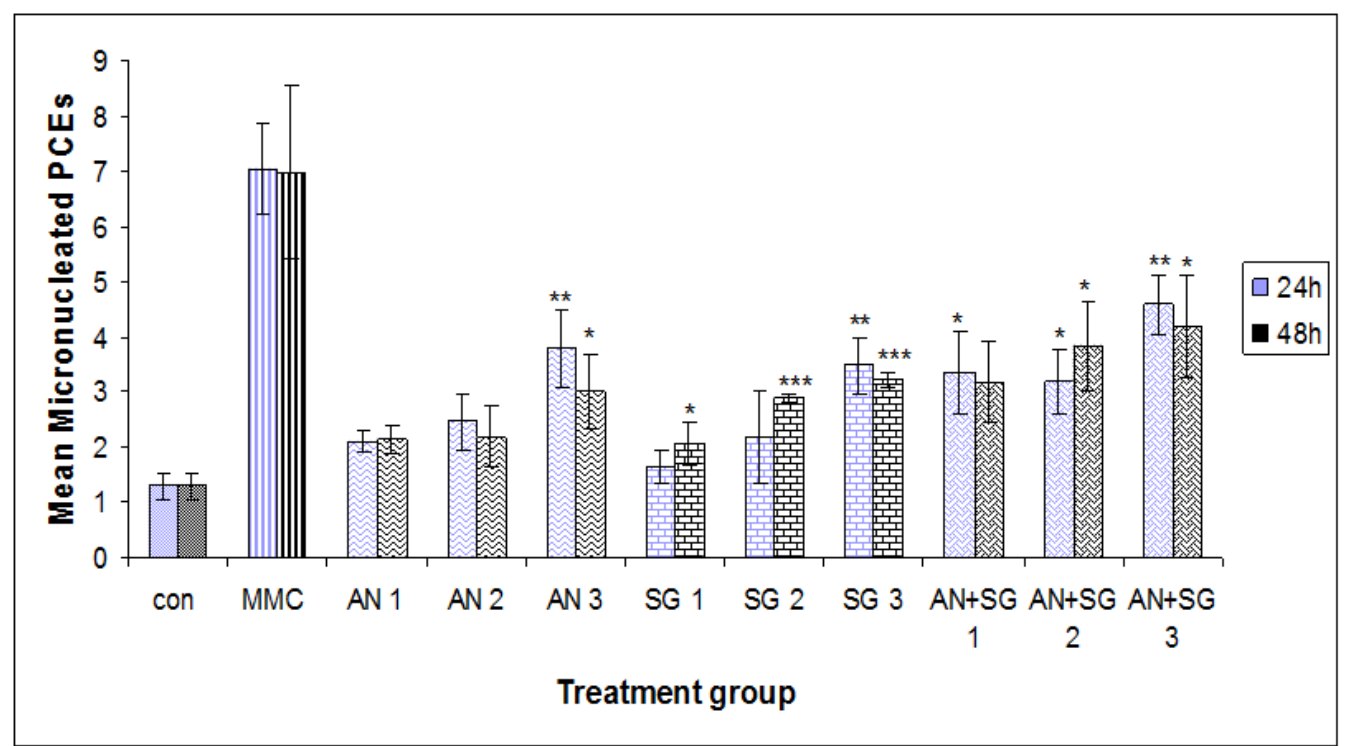

\section{Figure 7:}

Histograms showing the comparative study of the frequency of micronucleated polychromatic erythrocytes after 24 hour and 48 hour exposure in the bone marrow cells following areca nut and sadagura extracts alone or in combination treatment. Con $=$ Control group animals treated with solvent (DMSO) vehicle; MMC: Mitomycin C (2 mg/kg bw); AN1, AN2, AN3 = Areca nut extract (20, 50 and $80 \mathrm{mg} / \mathrm{kg}$ bw respectively); SG1, SG2, SG3 = Sadagura extract (20, 50 and $80 \mathrm{mg} / \mathrm{kg}$ bw respectively); AN+SG1, AN+SG2, $\mathrm{AN}+\mathrm{SG} 3=$ Areca nut with sadagura extract $(20,50$ and $80 \mathrm{mg} / \mathrm{kg}$ bw respectively). $*=\mathrm{P}<0.05, * *=\mathrm{P}<0.01$ and $* * *=\mathrm{P}<0.001$ significantly different from control. 


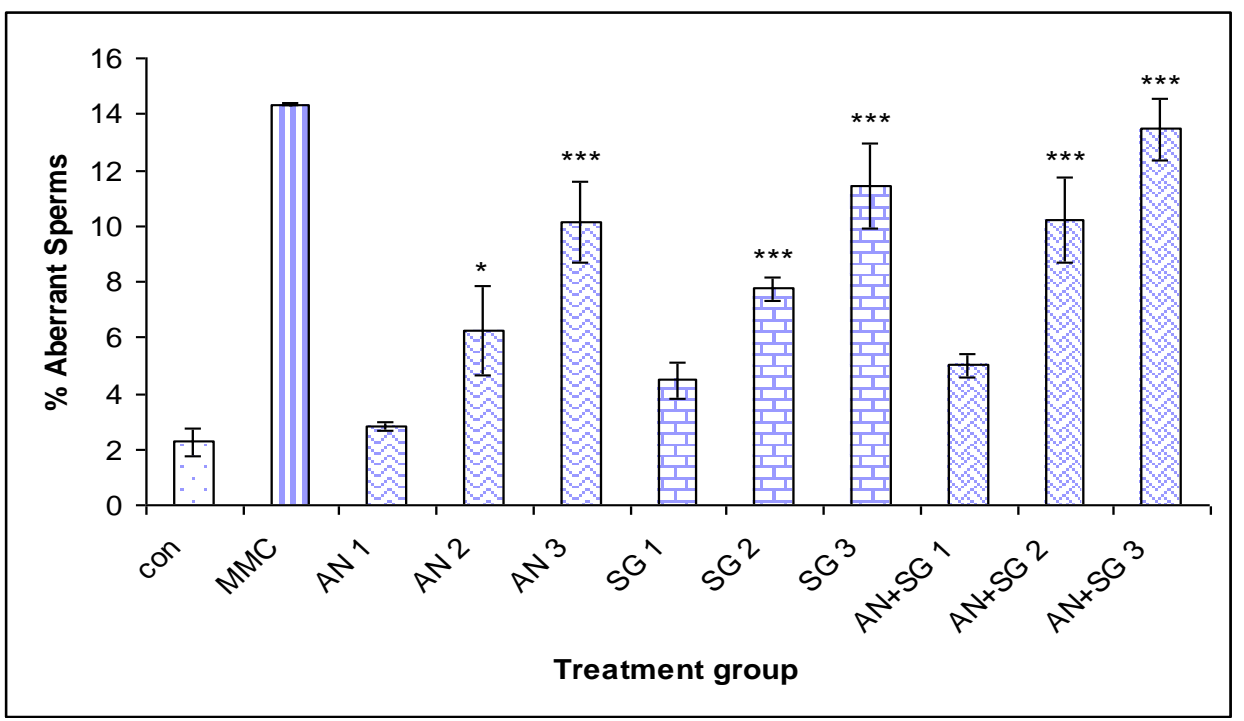

\section{Figure 8:}

Histogram showing the comparative study of the frequency of sperms with abnormal head morphology after 35 days of exposure in mice following areca nut and sadagura extracts alone or in combination treatment. Con $=$ Control group animals treated with solvent (DMSO) vehicle; MMC: Mitomycin C (2 mg/kg bw); AN1, AN2, AN3 = Areca nut extract (20, 50 and $80 \mathrm{mg} / \mathrm{kg}$ bw respectively); SG1, SG2, SG3 = Sadagura extract $(20,50$ and $80 \mathrm{mg} / \mathrm{kg}$ bw respectively); AN+SG1, AN+SG2, AN+SG3 = Areca nut with sadagura extract $\left(20,50\right.$ and $80 \mathrm{mg} / \mathrm{kg}$ bw respectively). $*=\mathrm{P}<0.05,{ }^{*}=\mathrm{P}<0.01$ and $* * *=\mathrm{P}<0.001$ significantly different from control

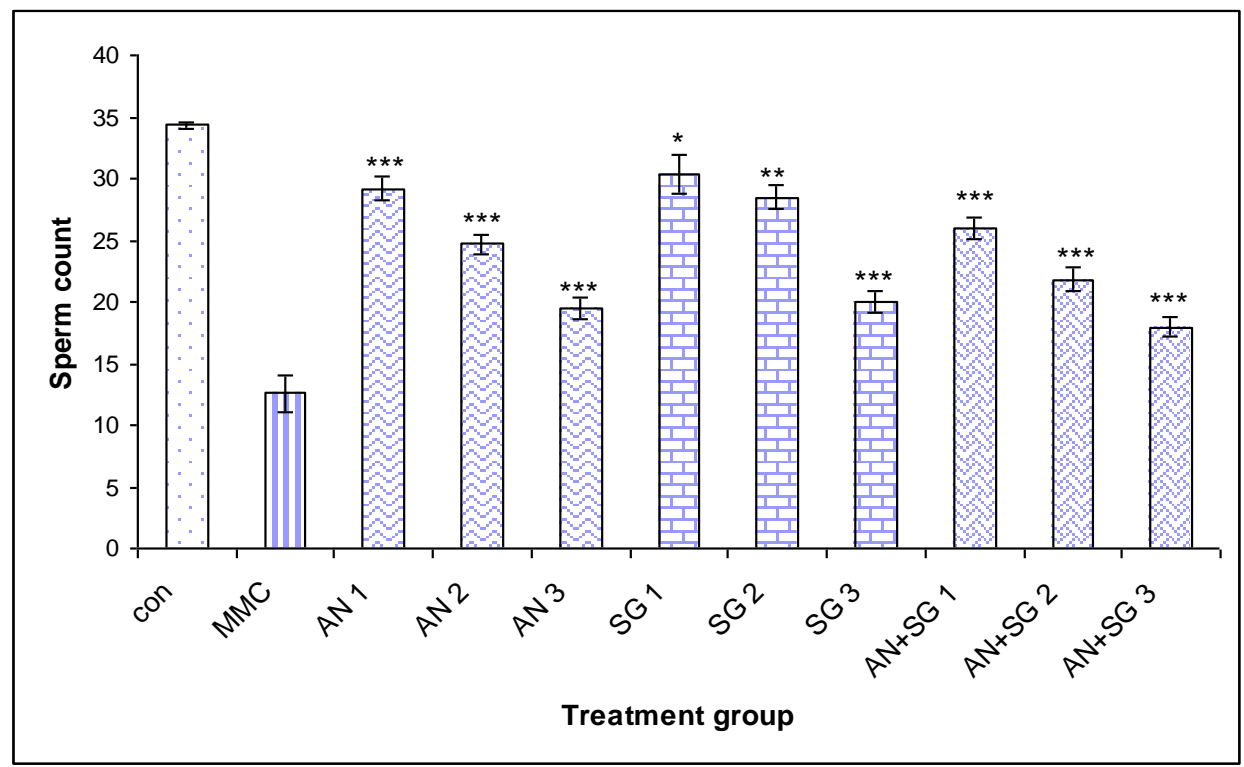

\section{Figure 9:}

Histogram showing the comparative study of the effect on total sperm count $\left(\mathrm{x} 10^{6}\right)$ after 35 days of exposure in mice following areca nut and sadagura extracts alone or in combination treatment. Con $=$ Control group animals treated with solvent (DMSO) vehicle only; MMC: Mitomycin C (2 mg/kg bw); AN1, AN2, AN3 = Areca nut extract (20, 50 and $80 \mathrm{mg} / \mathrm{kg}$ bw respectively); SG1, SG2, SG3 $=$ Sadagura extract $(20,50$ and $80 \mathrm{mg} / \mathrm{kg}$ bw respectively); AN+SG1, AN+SG2, AN+SG3 = Areca nut with sadagura extract $(20,50$ and $80 \mathrm{mg} / \mathrm{kg}$ bw respectively). $*=\mathrm{P}<0.05, * *=\mathrm{P}<0.01$ and $* * *=\mathrm{P}<0.001$ significantly different from control.

\section{REFERENCES}

[1] [1] R. Doll, R. Peto, The cause of cancer: quantitative estimates of avoidable risks of cancer in the United States today, J. Natl.Cancer Inst. 66 (1981) $1191-1308$.

[2] [2] R.K. Phukan, M.S. Ali, C.K. Chetia, J. Mahanta, Betel nut and tobacco chewing; potential risk factors of cancer of oesophagus in Assam, India, Br. J. Cancer 85 (2001) 661-667.

[3] [3] IARC. Smokeless tobacco and some tobacco-specific N-nitrosamines, IARC Monographs on the Evaluation of Carcinogenic Risks to Humans 89 (2007) 167201.

This publication is licensed under Creative Commons Attribution CC BY. 
[4] [4] A. Kausar, S. Giri, M. Mazumdar, A. Giri, P. Roy, P. Dhar, Micronucleus and other abnormalities among betel quid chewers with or without sadagura, a unique smokeless tobacco preparation, in a population from North- East India, Mutat. Res. 677 (2009) 72-75.

[5] [5] C.S. Muir, The oral cavity, in: R.W. Raven, F.J.C. Roc (Eds.), The prevention of Cancer, Butterworths, London, 1967, 71-77.

[6] [6] P. Balaram, K.R. Nalinakumari, E. Abraham, A. Balan, N.K. Hareendran, H.U. Bernard, S.Y. Chan, Human papilloma viruses in 91 oral cancers from Indian betel quid chewers-high prevalence and multiplicity of infections, Int. J. Cancer 61 (1995) 450-454.

[7] [7] B.J. Dave, A.H. Trivedi, S.G. Adhvaryu, In vitro genotoxic effects of areca nut extracts and arecoline, J. Cancer Res. Clin. Oncol., 118(4) (1992) 283-288.

[8] [8] D. Samrat, U. Puja and G. Sarbani, Arsenic and smokeless tobacco induce genotoxicity, sperm abnormality as well as oxidative stress in mice in vivo Genes Environ. 38 (2016) 4. doi: 10.1186/s41021-016-0031-2

[9] [9] G. Krishna, and M. Hayashi, In Vivo rodent micronucleus assay: Protocol, conduct and data interpretation. Mutat Res., 455 (2000) $155-166$.

[10] [10] M. Mazumdar, S. Giri, A. Giri, Role of quercetin on mitomycin C induced genotoxicity: Analysis of micronucleus and chromosome aberrations in vivo. Mutat Res. 721 (2011) 147-152.

[11] [11] S. Singh, A. Giri, S. Giri, The antimalarial agent artesunate causes sperm DNA damage and hepatic antioxidant defense in mice. Mutat Res. 777 (2015) 1-6.

[12] [12] S. Giri, A. Giri, G.D. Sharma, S.B. Prasad, Mutagenic effects of carbosulfan, acarbamate pesticide. Mutat Res. 519 (2002) 75-82.

[13] [13] S. Giri, S.B. Prasad, A. Giri, G.D. Sharma, Genotoxic effects of malathion:an organophosphorus insecticide, using three mammalian bioassays in vivo. Mutat Res. 514 (2002) 223-231.

[14] [14] S.C. Joshi, R. Mathur, A. Gajraj, T. Sharma, Influence of methyl parathion on reproductive parameters in male rats. Environ Toxicol Pharmacol. 14 (2003) 91-98.

[15] [15] Shafig-U-Rehman, Lead-induced regional lipid peroxidation in brain. Toxicol Lett., 21(3) (1984) 333-337.

[16] [16] S.V. Bhide, N. Ammigan, U.J. Nair and V.S. Lalitha, Carcinogenicity studies of tobacco extract in vitamin A-deficient Sprague-Dawley rats. Cancer Res., 51 (1991) 3018-3023.

[17] [17] Preston, R.J., Dean, B.J., Galloway, S., Holden, H., McFe, A.F. and Shelby, M. Mammalian in vivo cytogenetic assays: analysis of chromosome aberrations in bone marrow cells. Mutat Res., 189 (1987) 157-165.

[18] [18] W. Schmid, The micronucleus test, Mutat Res. 31(1) (1975) 9-15.

[19] [19] Wyrobek, A.J. and Bruce, W. R. Chemical induction of sperm head abnormalities in mice. Proceedings of National Academy of Science U.S.A., 72(1975) 4425-4429.

[20] [20] Narayana, K., D’Souza, U.J.A. and Rao, K.P.S. Effect of ribavirin on epididymal sperm count in rat. Indian J. Physiol. Pharmacol., 46 (1) (2002) 97-101.

[21] [21] Vega, S.G., Guzman, P., Garcia, L., Espinosa, J. and De Nava, C.C. Sperm shape abnormality and urine mutagenicity in mice treated with niclosamide. Mutat. Res., 204(1988) 269-276.

[22] [22] Narayana, K., Prashanta, N., Nayanatara, A., Harish Chandra, H.K., Abhilash, K. and Bairy, K.L. Effects of methyl parathion [o,o-dimethyl o-4-nitrophenyl phosphorothioate] on rat sperm morphology and sperm count, but not fertility, are associated with decreased ascorbic acid level in the testis. Mutat. Res., 588 (2005) 28-34.

[23] [23] Auger, J., Kunstmann, J.M., Czyglik, F. and Jouannet, P. Decline in semen quality among fertile man in Paris during the past 20 years. New Engl. J. Med., 332(1995) 281-285.

[24] [24] Wenke G, Brunneman KD, Hoffmann D, Bhide SV. A study of betel quid carcinogenesis. IV. Analysis of the saliva of betel chewers: a preliminary report. J Cancer Res Clin Oncol. 108(1984) 110-113.

[25] [25] Riebe M, Westphal K. Studies on the induction of sister chromatid exchanges in Chinese hamster ovary cells by various tobacco alkaloids. Mutat Res. 124 (1983) 281-286.

[26] [26] M. Hashibe, B. Mathew, B. Kuruvilla, G. Thomas, R. Sankaranarayanan, D.M. Parkin, Z.F. Zhang, Chewing tobacco, alcohol and the risk of erythroplakia, Cancer Epidemiol. Biomarkers Prev. 9 (2000) 639-645.

[27] [27] Hunter KD, Parkinson EK, Harrison PR, Profiling early head and neck cancer. Nat Rev Cancer 5(2005) 127- 135.

[28] [28] Emilios Gemenetzidis, Amrita Bose, Adeel M. Riaz, Tracy Chaplin, Bryan D. Young, Muhammad Ali, David Sugden, Johanna K. Thurlow, Sok-Ching Cheong, Soo-Hwang Teo, Hong Wan, Ahmad Waseem, Eric K. Parkinson, Farida Fortune, Muy-Teck Teh, FOXM1 Upregulation is an early event in human squamous cell carcinoma and it is enhanced by nicotine during malignant transformation. PLoS ONE 4(3) (2009):e4849.

[29] [29] Walker DM, Boey G, McDonald LA, The pathology of oral cancer. Pathology 35(2003) 376- 383.

[30] [30] Huang LW, Hsieh BS, Cheng HL, Hu YC, Chang WT, Chang KL. Arecoline decreases interleukin-6 production and induces apoptosis and cell cycle arrest in human basal cell carcinoma cells. Toxicology and applied pharmacology. 258(2): (2012) 199-207.

[31] [31] Chojnacka K, Papke RL, Horenstein NA. Synthesis and evaluation of a conditionally-silent agonist for the alpha7 nicotinic acetylcholine receptor. Bioorganic \& medicinal chemistry letters. 23(14): (2013) 4145-9.

[32] [32] Thangjam GS, Kondaiah P. Regulation of oxidative- stress responsive genes by arecoline in human keratinocytes. J Periodont Res 44(2009) 673-682.

[33] [33] S. Giri, R. Jeffrey, J.R. Idle, C. Chen, T.M. Zabriskie, K.W. Krausz, F.J. Gonzalez, A metabolomic approach to the metabolism of the areca nut alkaloids arecoline and aracaidine in the mouse, Chem. Res. Toxicol. 19 (2006) 818-827.

[34] [34] M.C. Chang, Y.S. Ho, P.H. Lee, C.P. Chan, J.J. Lee, L.J. Hahn, Y.J. Wang, J.H. Jeng, Areca nut extract and arecoline induced the cell cycle arrest of cultured oral KB cells: association of glutathione, reactive oxygen species and mitochondrial membrane potential, Carcinogenesis 22 (2001) 1527-1535.

[35] [35] Topham JC. Chemically induced transmissible abnormalities in sperm head shape. Mutat Res. 1980; 70:109-114.

[36] [36] Bruce WR, Heddle JA. The mutagenic activity of 61 agents as determined by the micronucleus, Salmonella and sperm abnormality assays. Canada J Genetic Cytol. 21(1979) 319-334.

[37] [37] Odeigah PGC. Sperm-head abnormalities and dominant lethal effects of formaldehyde in albino rats. Mutat Res. 389(1997) 141-148.

[38] [38] Jeng J.H., Ho, Y.S., Chan, C. P., Wang, Y.J., Hahn, L.J., Lei, D., Hsu, C.C. and Chang, M.C. Areca nut extract up- regulates prostaglandin production, cyclooxygenase-2 mRNA and protein expression of human oral keratinocytes. Carcinogenesis, 21(2000) 1365- 1370.

[39] [39] U.J. Nair, G. Obe, M. Friesen, M.T. Goldberg, H. Bartsch, Role of lime in the generation of reactive oxygen species from betel quid ingredients, Environ. Health Perspect. 98 (1992) 203- 205.

[40] [40] Romi Dasguta, Indraneel Saha, Suman Pal, Arindam Bhattacharyya, Gaurisankar Sa, Tapas C. Nag, Tania Das, B.R. Maiti, Immunosuppression, hepatotoxicity and depression of antioxidant status by arecoline in albino mice Toxicology 227(2006) 94-104. 


\section{AUTHORS}

First Author - Dr. SALAM HIMIKA DEVI, Guest Faculty Genetics and Genotoxicology Branch, Department of Zoology (Life Sciences), Manipur University, Type III Quarter new block near community hall, 1st floor, Western side, Room no. 32, IndoMyanmar Road, Canchipur-795003, Imphal-West, Manipur, India, Contact: +91 7085223641, e-mail: himikasalam6@gmail.com 